This is the author's final, peer-reviewed manuscript as accepted for publication. The publisher-formatted version may be available through the publisher's web site or your institution's library.

\title{
Effects of CDS and drying temperature on the flowability behavior of DDGS
}

Rumela Bhadra, K. Muthukumarappan, Kurt A. Rosentrater

\section{How to cite this manuscript}

If you make reference to this version of the manuscript, use the following information:

Bhadra, R., Muthukumarappan, K., \& Rosentrater, K. A. (2012). Effects of CDS and drying temperature on the flowability behavior of DDGS. Retrieved from http://krex.ksu.edu

\section{Published Version Information}

Citation: Bhadra, R., Muthukumarappan, K., \& Rosentrater, K. A. (2012). Effects of CDS and drying temperature on the flowability behavior of DDGS. Drying Technology: An International Journal, 30(5), 542-558.

Copyright: Copyright 2012 Taylor \& Francis Group, LLC

Digital Object Identifier (DOI): doi:10.1080/07373937.2011.649510

Publisher's Link: http://www.tandfonline.com/doi/abs/10.1080/07373937.2011.649510

This item was retrieved from the K-State Research Exchange (K-REx), the institutional repository of Kansas State University. K-REx is available at http://krex.ksu.edu 


\section{TITLE: EFFECTS OF CDS AND DRYING TEMPERATURE LEVELS ON THE FLOWABILITY BEHAVIOR OF DDGS}

3

4

\section{Author(s)}

Rumela Bhadra, PhD, Post-Doctoral Research Associate, BAE Department, Kansas State University, Manhattan, Kansas. Email: rumelabhadra31@yahoo.com

Address: 147 Seaton Hall, BAE Department, Kansas State University, Manhattan, KS 66502

K. Muthukumarappan, PhD, Professor, Department of Agricultural and Biosystems

Engineering, South Dakota State University, South Dakota. Email: muthukum@sdstate.edu

Address: 1400 North Campus Drive, South Dakota State University, Brookings, SD 57007

Kurt A. Rosentrater, PhD, Assistant Professor, Department of Agricultural and Biosystems

Engineering, Iowa State University, IA. Email: karosent@iastate.edu

Address: Iowa State University, Department of Agricultural and Biosystems Engineering, 3167

NSRIC Building, Ames, IA 50011

Corresponding author: Kurt A. Rosentrater, PhD, Assistant Professor, Address: Iowa State University, Department of Agricultural and Biosystems Engineering, 3167 NSRIC Building, Ames, IA 50011. Email: karosent@iastate.edu

Phone: (515) 294-4019; Fax: (515) 294-6633 
22 Due to increasing demand for alternative fuels and the need to reduce dependence on fossil

23 fuels, the growth of bioethanol production has been rising. One of the problems facing this

24 industry is transportation of the coproduct distillers dried grains with solubles (DDGS)

25 over long distances, because caking and agglomeration between particles can lead to bulk

26 flow problems. In this study DDGS was prepared by combining condensed distillers

27 solubles (CDS) and distillers wet grains (DWG), and then oven drying to achieve $8 \%$ (db)

28 moisture content. The effects of drying temperature (100, 200, and $\left.300^{\circ} \mathrm{C}\right)$ and CDS (10,

2915 , and $20 \% \mathrm{wb}$ ) level on the resulting flowability behavior of the DDGS particles were

30 investigated. Statistical analyses indicated significant differences $(\alpha=0.05,95 \%$

31 confidence level) due to drying temperature and CDS main effects, and also significant

32 interaction effects between CDS level and drying temperature for many of the flow

33 parameters. Surface regression analysis of the ratio of Total Flow Index/Jenike Flow

34 Function as a function of CDS and drying temperature resulted in an $\mathrm{R}^{2}$ value of 0.94 .

35 Partial Least Squares (PLS) regression yielded an $\mathrm{R}^{2}$ of 0.90 for the Jenike Flow Function

36 Index as a function of all flow and physical properties, using only two multivariate

37 components. Understanding the effects of varying drying temperature and CDS levels can

38 help guide efforts to overcome DDGS flowability problems.

39 Keywords. Agglomeration, Caking, Carr, Condensed distillers solubles, Distillers wet 40 grains, Jenike. 


\section{INTRODUCTION}

42

Distillers dried grains with solubles (DDGS) is a coproduct from the corn-based fuel ethanol industry, and is relatively high in protein and fiber content but low in starch. Due to its nutrient content and digestibility, it is primarily used as livestock feed for beef and dairy rations, and to some extent in swine and poultry diets. Research has also been done on using DDGS in aquaculture feed (1) As there is growing demand for fuel ethanol, there is more production of DDGS as well. It has been reported that during the fiscal year of 2008-2009, over 19 million metric tons of DDGS was produced from the ethanol industry in United States (2), and this level has risen to more than 30 million metric tons in 2010 .

In order to optimize the use of DDGS in livestock feed markets, it is therefore essential to provide safe and economic handling of DDGS while it is being transported in domestic as well as international markets. Distillers dried grains with solubles storage and transportation is often problematic due to formation of particle agglomerates inside storage structures, which results in “caking" and restricts flow during discharge. Flowability problems may be due to varied environmental conditions and storage situations, such as temperature, moisture content, humidity, and storage period. Apart from environmental conditions, the inherent physical and chemical properties of the material may also affect overall flowability of DDGS $(3 ; 4 ; 5)$.

Cohesiveness and flow problems create unwanted labor and cost to unload (6).

Most organic materials (like DDGS) are hygroscopic in nature, so they have the tendency to gain or lose moisture when they are exposed to diverse humidity conditions. This can lead to possible changes in physical and chemical properties in the material itself, which in turn will affect the flowability and can cause hardening of particles. 
Condensed Distillers Solubles (CDS), commonly known as "solubles" or "syrup," is mixed

65 with distillers wet grains (DWG) and then dried to produce distillers dried grains with solubles

66 (DDGS). The solubles are relatively high in vitamins, fat $(6-21 \%, \mathrm{db})$, and protein $(9-12 \%, \mathrm{db})$,

67 but low in fiber $(<5 \%, \mathrm{db})$. Syrup has a total digestible energy value approximately $91 \%$ that of

68 raw corn (7). DDGS typically contains approximately 86 to $93 \%$ dry matter, 3 to $13 \%$ (db) fat,

69 and 26 to $34 \%(\mathrm{db})$ protein (8). The high fat level in CDS may be a possible cause for DDGS

70 flowability problems, because the corn lipids may form molten bridges between the particles

71 Stickiness in corn syrup powders was determined under varying temperature and humidity

72 conditions (9). The effect of temperature, moisture content, and storage time was studied for milk

73 powder flowability and stickiness $(10 ; 11 ; 12)$. It has been found that powder caking is often a

74 function of moisture content, and frequently there is an increase in stickiness due to an increase

75 in ambient temperature $(13 ; 14)$.

$76 \quad$ Powder flowability is most commonly assessed using Carr (15) and Jenike (16) shear test

77 procedures. Parameters for flowability in the Carr (15) test procedure include Angle of Repose

78 (AoR), Aerated and Packed Bulk Density (ABD and PBD), Compressibility (Cc), Angle of

79 Spatula (AoS), Angle of Difference (AoD), Uniformity, Angle of Fall (AoF), Dispersibility, and

80 Total Flow and Flood Indices. Hausner Ratio is defined as the ratio of tapped bulk density to the

81 aerated (or apparent) bulk density (i.e., PBD/ABD). Values less than 1.25 typically indicate good

82 flow, whereas values greater than 1.25 generally indicate poor flow (17). Angle of Spatula is

83 measured by inserting a flat blade into a pile of powder and then lifting it up. After the

84 evaluation of the above properties (i.e., Angle of Repose through Uniformity) (excluding

85 Hausner Ratio), the index values are combined to provide an overall flowability index value for 
86 the powder/bulk solid under investigation. The smaller the uniformity value, the more

87 homogenous the particle shapes are, and typically the less the flow problem $(15,17)$.

88 After the overall (or total) flowability index has been determined, then the floodability

89 assessment is done. The Angle of Fall, the Angle of Difference, and Dispersibility is measured as

90 part of floodability index. The above properties (Angle of Fall, Angle of Difference, and

91 Dispersibility, in addition to Flow Index) are numerically combined to calculate the Total

92 Floodability Index of the bulk solid (by summation of the individual indices). The angle of fall is

93 the new angle of repose that is formed after impaction has been applied to the material. More

94 detailed information on these properties and testing procedures can be found in Carr (15) and

95 Bhadra et al. (3).

Another procedure which is used commonly to assess flow behavior is Jenike (16) shear

97 testing. In this type of test, when the powder is subjected to a normal stress $(\sigma)$, there will be a

98 particular shear stress $(\tau)$ which causes bulk failure (i.e., flow). This data gives the yield locus

99 curve which can be used to compute the angle of internal friction ( $\Phi$, degrees), effective angle of

100 internal friction ( $\delta$, degrees), major consolidation stress $\left(\sigma_{1}, \mathrm{kPa}\right)$, and unconfined yield strength $101\left(\sigma_{\mathrm{c},} \mathrm{kPa}\right)$.

Unconfined yield strength is a measure of the compressive strength $(\mathrm{kPa})$ of the granular

103 solid (18). Major consolidation stress is determined as the point of intersection between the Mohr

104 circle (drawn with a shear and normal stress plot) and the stress x-axis. Flow Function Index

105 (dimensionless) is the ratio of the major consolidation stress to unconfined yield strength.

106 Depending on the value of this index, the flow behavior of a material can be categorized as

107 "good flow", "fair to passable flow," or "cohesive flow." More details on this can be found in

108 Jenike (16) and Bhadra et al (3). 
Some work has previously examined DDGS flowability, including use of flow agents,

110 measuring physical and chemical properties and correlating them with the Carr and Jenike shear

111 test properties $(19 ; 20 ; 21 ; 22)$. Reduced fat and normal DDGS samples have been studied to

112 understand flow properties, and reduced fat DDGS had slightly better flow that normal DDGS

113 (5). Previous work has also shown the effects of moisture content and CDS addition levels on

114 DDGS flowability (19). Development of a predictive flowability model $\left(\mathrm{R}^{2}=0.94\right)$ using

115 exploratory data analysis techniques was accomplished (21). A comprehensive dynamic water

116 adsorption model $\left(\mathrm{GRM}\right.$ model, $\left.\mathrm{R}^{2}=0.94\right)$ incorporating varying CDS, relative humidity, and

117 drying temperature levels has been developed $(22)$. A model $\left(\mathrm{R}^{2}=0.94\right)$ to predict the sorption

118 isotherm behavior of DDGS with varying CDS and equilibrium moisture content levels was also

119 developed (23). Various studies have also revealed the typical ranges of DDGS chemical,

120 physical, and flowability properties $(3 ; 4 ; 24)$.

The functionality and properties of bulk solids and granular materials are greatly

122 influenced by drying conditions during the manufacturing process $(46,47,48,49)$. Two studies

123 examined drying rate and moisture desorption during DDGS production, using varying CDS and

124 drying temperature levels $(25 ; 26)$. Those studies were able to establish regression models of the 125 drying kinetics and moisture desorption behavior; but no correlational studies between the

126 resulting flowability properties and the effects of drying temperature and CDS addition levels

127 were performed. Understanding these effects on physical and flow properties is an essential step

128 toward improving DDGS flowability.

129 Therefore, the objectives of this study were: 1) to prepare DDGS samples under

130 laboratory conditions using CDS and DWG using multiple ratios of CDS:DWG and multiple

131 drying temperatures; 2) to measure several physical and flow properties (both Carr and Jenike 
132 flow properties) of the prepared DDGS samples; 3) to determine the effects of drying

133 temperature and CDS addition levels on the resulting properties of the DDGS; and 4) to examine

134 predictive regression models of various DDGS properties to fully understand the effects CDS

135 level and drying temperature.

136

137 154 behavior. To achieve this, each treatment combination was dried at different drying times. The 155 drying time slightly varied while changing the CDS levels: it was around $60 \mathrm{~min}, 35 \mathrm{~min}$, and 15

\section{MATERIALS AND METHODS}

\section{Sample Collection and Preparation}

Samples of distillers wet grains (DWG) and condensed distillers solubles (CDS) were collected from a commercial fuel ethanol plant in South Dakota and were stored under refrigerated conditions $\left(10 \pm 1^{\circ} \mathrm{C}\right)$. The initial moisture content of the DWG and CDS samples were between $45 \%(\mathrm{db})$ to $47 \%(\mathrm{db})$. Prior to the drying experiments, CDS was added to DWG at several predetermined levels $(10,15$, and $20 \%, w b)$, and then thoroughly mixed in a laboratory mixer (model D300, Hobart Corporation, Troy, OH) for 5 min. After blending, each combined sample (approximately $350 \mathrm{~g}$ of mixed DWG and CDS) was spread uniformly on a thin aluminum plate $(38 \mathrm{~cm} \times 27 \mathrm{~cm} \times 2 \mathrm{~cm})$ and then dried in a laboratory-scale oven (model $838 \mathrm{~F}$, Fisher Scientific, Pittsburg, PA). For a single drying temperature and CDS combination, three aluminum trays were used. Drying was done at three selected temperatures (100, 200, and $300^{\circ} \mathrm{C}$ ) for each DWG/CDS mixture. Temperature selection was based on interviews and discussions with industry experts, and also based on our previous studies of drying rate and moisture content of DDGS $(25 ; 26)$. For each temperature/CDS combination, drying was done to reduce all the experimental samples to a target of $8 \%(\mathrm{db})$ moisture content, in order to have common baseline moisture content and eliminate its possible influence on the flowability 
$156 \min$ for drying temperatures of 100,200 , and $300^{\circ} \mathrm{C}$, respectively. The drying continued until the

157 final blend moisture contents reached $8 \%(\mathrm{db})$. This target was based on previous research by

158 Bhadra et al. (24) and Rosentrater (27), and upon discussions with industry representatives

159 (unpublished), which indicated a typical average moisture content of approximately $8 \%(\mathrm{db})$ in

160 the marketplace. Preparation of the dried DDGS samples (9 total treatments) was done with

161 three replications.

\section{Experimental Design}

Experiments were conducted using a $3 * 3$ full factorial design, with 3 drying temperatures

$165\left(100,200\right.$, and $\left.300^{\circ} \mathrm{C}\right)$ and $3 \mathrm{CDS}$ addition levels $(10,15$, and $20 \%$, wb), yielding a total of 9

166 treatment combinations. These treatment combinations were implemented using a completely

167 randomized design. DDGS samples were prepared in three replications, thus yielding $3 * 3 * 3=27$

168 experimental runs. Each physical and flow property was determined using three replicate

169 measurements for each treatment combination.

170 Once the drying was completed, the granular particles of each sample were cooled for 6

171 to $8 \mathrm{~h}$ under ambient conditions $\left(\sim 25^{\circ} \mathrm{C}\right)$, and then placed in polyethylene bags and stored at

172 room temperature $\left(25^{\circ} \mathrm{C}\right)$, throughout the duration of the study. After the drying was completed

173 for all 27 experimental runs, the physical and flow properties were then measured.

\section{Flowability Property Measurement}

175 A powder characteristics tester (Model PTR, Hosokawa Micron Powder Systems, Summit, $176 \mathrm{NJ}$ ) was used to measure the Carr (15) flow properties of the DDGS, following the procedures 177 described by ASTM D6393 (28). The Carr flow properties included AoR, ABD, PBD, 
178 Compressibility, Uniformity, AoF, AoS, AoD, and Dispersibility. These parameters were then

179 used to determine both the Total Flow Index and Total Floodability Index.

AoR is defined as the angle formed between the slope of a pile of material and a horizontal

181 plane. $\mathrm{ABD}$ and $\mathrm{PBD}$ are used to assess compressibility and the ability of the material to entrap

182 air in pores between particles (29). Packed (or tapped) density is an actual representation of a

183 material's bulk density when it is stored in bins or transported over large distances (i.e., in a rail

184 car as entrained air is forced out). Angle of Spatula is measured by inserting a flat blade into a

185 pile of material and then lifting it up. The new Angle of Repose which the material forms relative

186 to the horizontal plane of the blade gives the Angle of Spatula. Uniformity is the ratio of the

187 width of the sieve opening that will allow $60 \%$ of the material to pass to the width of sieve

188 opening that will only allow $10 \%$ of the sample to pass. Uniformity thus gives a relative measure

189 of the homogeneity of the size and shape of the particles. Uniformity is the ratio obtained

190 between the width of sieve opening that will pass $60 \%$ of the sample to the width of sieve

191 opening that will pass only $10 \%$ of the sample. Particle size distributions were determined using

192 standard US sieves, from no. 4 (pore opening size of $4.76 \mathrm{~mm}$ ) to 270 (pore opening size of 53

$193 \mu \mathrm{m})$. Thus, the Total Flow Index was determined by adding the Angle of Repose, Uniformity,

194 Compressibility, and Angle of Spatula.

195 After the overall flowability index has been determined, then floodability is assessed. The

196 Angle of Fall is the new angle of repose that is formed after impaction (by the impactor device

197 provided on the Hosokawa Micron Powder System Unit) has been applied to the material. It is

198 done to simulate the disturbance due to vibrations and transport effects on bulk solids (15). . The

199 Angle of Difference is then calculated by subtracting the Angle of Fall from the Angle of

200 Repose. Dispersibility is measured by discharging a specified amount (10 g) of material through 
201 a column onto a watch glass $98 \mathrm{~cm}$ diameter); the quantity of material left behind on the watch

202 glass quantifies how disperse the material is. Hence, Total Floodability Index was determined by

203 adding the Angle of Fall, Angle of Difference, Dispersibility, and Total Flow Index.

204 The other flowability behavior is measured by Jenike (16) shear testing. This method uses 205 a split, horizontal testing container, and various normal stresses and shear stresses are applied to 206 the top half, while the lower half is kept stationary. In this type of test, when the powder is 207 subjected to a normal stress $(\sigma)$, there will be a particular shear stress $(\tau)$ which causes bulk 208 failure (i.e., flow). This data gives the yield locus curve, which can then be used to compute the 209 angle of internal friction ( $\Phi$, degrees), effective angle of internal friction ( $\delta$, degrees), major 210 consolidation stress $\left(\sigma_{1}, \mathrm{kPa}\right)$, and unconfined yield strength $\left(\sigma_{\mathrm{c}}, \mathrm{kPa}\right)$. Angle of internal friction

211 is the inter-particle friction as the bulk solid tends to slide on itself at the onset of flow. Effective 212 angle of internal friction is measured during flow when granular solids are constantly exposed to 213 pressures. The major pressure acting on a particle element is denoted by $\sigma_{1}$ while the minor 214 pressure is termed $\sigma_{2}$. The relationship between these two pressures varies slightly with changes 215 in temperature for most bulk solids (1964). Their relationship can be expressed as:

$$
\frac{\sigma_{1}}{\sigma_{2}}=\frac{1+\sin \delta}{1-\sin \delta}
$$
compressive strength $(\mathrm{kPa})$ of the granular solid (18). Major consolidation stress is determined as

222 the point of intersection between the Mohr circle and the stress X-axis. Major consolidation stress 
$223\left(\sigma_{1}, \mathrm{kPa}\right)$ was calculated from the Mohr circles, which are drawn from the equation of effective yield

224 function (i.e., equation 1). The point where the largest Mohr circle intersects the normal stress axis (i.e.,

$225 \mathrm{x}$-axis) gives $\sigma_{1}$. Additionally, $\sigma_{\mathrm{c}}$ (unconfined yield strength, $\mathrm{kPa}$ ) was determined from the Mohr circle as

226 well. It is the intersection of the smaller Mohr circle on the normal stress axis. Flow Function Index

227 (dimensionless) is the ratio of the major consolidation stress $\left(\sigma_{1}, \mathrm{kPa}\right)$ to unconfined yield

228 strength $\left(\sigma_{\mathrm{c}}, \mathrm{kPa}\right)$.

229

Jenike (16) shear testing was then performed to quantify the instantaneous shear behavior

230 for each DDGS sample, including angle of internal friction, effective angle of internal friction,

231 major consolidation stress, unconfined yield strength, and Jenike Flow Index. A Jenike shear cell

232 unit was used (Model ST-5, Jenike and Johansson Co., Westford, MA) following the procedures

233 described in ASTM D6128 (30). Jenike compressibility testing was also performed using the

234 same shear cell unit, but using the technique discussed in ASTM D6683 (31).

235 Physical Property Measurement

236 Color and thermal properties are not directly correlated with flowability properties of

237 DDGS however, there can some indirect effects. For example, color and brightness of a product

238 can indicate the level of nutrients (carbohydrates, lipids, fiber, etc.), which can, in turn, affect the

239 flow properties of DDGS. Similarly, thermal properties can correlate to frictional properties,

240 which, in turn, affect flow behavior. Water activity changes can indicate shelf life. PDI provides

241 a measure of protein solubility, which interacts with surface moisture films between DDGS

242 particles.

243 Color was measured using a spectrophotocolorimeter (LabScan XE, Hunter Associates

244 Laboratory, Reston, VA) with the L-a-b color scale (Hunter Associates Laboratory Universal

245 Software Manual V. 2.5; Reston; VA). Water activity was measured using a calibrated water 
246 activity meter (AW Sprint TH 500, Novasina, Talstrasse, Switzerland) using factory-supplied

247 standards. Thermal properties (conductivity, diffusivity, and resistivity) were determined with a

248 thermal properties meter (KD2, Decagon Devices, Pullman, WA) that utilized the line heat

249 source probe technique (32). Geometric mean diameter (GMD) (average particle size) was

250 determined by ASAE standard method S319.3 (33) with a Rotap sieve shaker (model RX-29,

251 Tyler Manufacturing, Mentor, OH). Porosity of the DDGS samples was calculated from the

252 method described in Sahin and Sumnu (34) using a multivolume pycnometer (model 1305,

253 Micromeritics, Norcross, GA). The protein dispersibility index (PDI) was calculated using

254 AACC method 46-24(35).

255 Statistical Analysis

256 Formal statistical data analyses were performed using Microsoft Excel v.2003 (Microsoft

257 Corp., Redmond, WA) and SAS v.8 (SAS Institute, Cary, NC) software. Analyses included

258 summary statistics, analysis of variance (at $\alpha=0.05$ ), and Least Significant Difference (LSD) (at

$259 \alpha=0.05$ ) testing; these were performed to determine significant differences and interaction

260 effects between the main effects and treatment combination effects due to drying temperature

261 and CDS level. Pearson linear correlation analysis among all properties was performed to

262 examine relationships at the 95\% confidence level. TableCurve 3D v.4.0.01 (SYSTAT Software,

263 Inc., San Jose, CA) was then used to develop regression equations and response surface models.

264 Partial Least Squares (PLS) and Principal Component Analysis (PCA) tests were then performed 265 using Minitab v.14 software (Minitab, State College, PA).

\section{RESULTS AND DISCUSSION}

\section{Main Effects, Interaction Effects and Treatment Combination Effects}


Table 1 gives the summary of the statistical output obtained after examining main effects

271 on all of the physical and flow properties. It was observed that there were significant differences

272 in the main effects for both CDS addition and drying temperature levels using the Least

273 Significant (LSD) test. To verify these differences, Tukey's significance test (TSD) at $\alpha=0.05$

274 was also performed, and similar significant differences (although they are not reported here) was

275 observed (36). Even for a conservative test like TSD, significant differences were observed for

276 most of the physical and flowability properties. Flowability of DDGS is a multivariate

277 phenomenon, as reflected by these results. Considerable variability in physical and flowability

278 properties was also found in commercial DDGS samples collected from various ethanol plants

279 (27).

280 These results also verify our hypothesis that drying temperature and CDS level results in 281 significant differences in DDGS properties. For example, there was a significant increase in

282 geometric mean diameter when drying temperature increased from $200(0.78 \mathrm{~mm})$ to $300^{\circ} \mathrm{C}$

$283(0.99 \mathrm{~mm})$. Even though the DDGS moisture content was constant for all the samples produced

$284(8 \% \mathrm{db}$, as stated earlier), higher drying temperatures produced larger particle sizes. Large

285 particle sizes generally result in decreased flow problems in bulk solids. Increasing CDS levels

286 from $10 \%(0.91 \mathrm{~mm})$ to $15 \%(0.75 \mathrm{~mm})$ resulted in a significant decrease in particle size,

287 indicating possible flow problems. However, geometric mean diameter showed an interaction

288 effect between CDS and temperature. CDS*temperature increased the particle size overall $(0.67$

289 to $1.31 \mathrm{~mm}$ ), except at $300^{\circ} \mathrm{C}$ (from 15 and $20 \% \mathrm{CDS}$ ), where particle size was slightly reduced

290 to $0.81 \mathrm{~mm}$. Angle of Repose increased $\left(42.06^{\circ}\right.$ to $\left.47.16^{\circ}\right)$ with increased CDS*temperature

291 combinations; higher angles indicate poorer flow. For water activity, CDS*temperature led to a 
292 decrease in value (from 0.71 to 0.23 ) as the temperature was increased. More details of

293 CDS*temperature interaction effects are discussed in later sections.

As shown in Table 2, there were also significant interaction effects $(\mathrm{p}<0.05)$ for varying

295 CDS levels and drying temperatures for most of the physical and flowability properties, except

296 for Hausner Ratio (HR, -) and Carr Compressibility (\%).

297 There were significant differences among treatment combinations (Table 3) observed for 298 most of trials. For a drying temperature of $100^{\circ} \mathrm{C}, \mathrm{HR}$, PDI, and Carr Compressibility did not

299 show any significant differences among the CDS levels (as indicated in bold letters). For a

300 drying temperature of $200^{\circ} \mathrm{C}, \mathrm{HR}, \mathrm{AoF}$, Hunter L (-) (which measures the brightness or

301 luminosity of a product), and thermal conductivity did not show significant differences among

302 the CDS levels. For drying temperature of $300^{\circ} \mathrm{C}, \mathrm{HR}$, Carr compressibility, Total Flow Index, 303 angle of internal friction, major consolidation stress, Hunter a(-) (which refers to the redness or 304 greenness of a product), and thermal conductivity did not shown any significant differences 305 among the CDS levels. Thus, it can be concluded that at lower drying temperatures, changes in 306 CDS levels can result in more variability in DDGS properties (both flow and physical), which 307 could lead to potential flow problems (3).

\section{Property Relationships}

309 Pearson product moment linear correlation analysis (37) was performed for the properties

310 in this study (Table 4). The correlation coefficient quantifies how closely two properties are

311 related to each other by a linear relationship. Only 19 combinations had $\mathrm{p}$ values less than $\alpha=$

3120.05 (i.e., were significant correlations) and had correlation coefficient (r) values greater than

3130.65 . Out of these 19 combinations, 10 combinations had $\mathrm{r}$ values from $|0.7|$ to $|0.8| ; 7$ variable

314 combinations had correlation coefficients from $|0.8|$ to $|0.9| ; 2$ combinations had $\mathrm{r}$ values from 
316 compressibility $\left(\mathrm{C}_{c}\right)$, which was anticipated because $\mathrm{HR}$ is calculated using $\mathrm{PBD}$ and $\mathrm{ABD}$,

317 which are basically the same parameters that are used to calculate $\mathrm{C}_{\mathrm{c}}$. Angle of Repose, an

318 important parameter for flowability assessment, showed moderate correlation with uniformity;

319 AoR is strongly dependent on the particle size and shape, and uniformity is measured via particle

320 size. Higher drying temperature will cause the moisture to evaporate more effectively, thereby

321 yielding lower water activity values, and hence improving the shelf life of the biomaterial.

322 However, higher drying temperatures can increase utility costs in bioethanol plants.

323 Drying temperature was found to correlate with most of the properties. These tie in to our

324 previous studies $(25,26)$ where mathematical modeling based on the same drying temperatures

325 and CDS levels were used. In these studies, it was found that temperature had more significant

326 effects on the drying behavior than CDS addition levels. It thus appears that drying temperature

327 is mainly responsible for differences in physical and flow properties as well.

\section{Effect of Drying Temperature and CDS Levels on Hausner Ratio (HR)}

Hausner Ratio (-) values ranged from 1.05 to 1.25 , depending on the drying temperature

330 and CDS level (Figure 1). HR depends on the friction in a moving powder mass (i.e., internal

331 friction) during the compaction of powders (38). Higher HR (>1.25) generally indicates poor

332 flowability. In this study, the HR values were mostly below 1.25. As the drying temperature

333 increased from 100 to $300^{\circ} \mathrm{C}$, the $\mathrm{HR}$ values decreased, indicating that higher temperatures

334 yielded better DDGS flowability, for all CDS levels. For the $10 \%$ CDS level, the $\mathrm{R}^{2}$ value $(0.16)$

335 obtained from the regression equation was much less than other two CDS levels, which was

336 probably due to the fact that there was substantial scatter in the data points at 100 and $300^{\circ} \mathrm{C}$.

337 More extensive study with greater replications may provide a better regression equation. 
However, for all CDS levels, the HR (-) decreased linearly with an increase in drying temperature, indicating better flow DDGS behavior. Effect of Drying Temperature and CDS Levels on Jenike Flow Index

Figure 2 presents the flowability behavior of the DDGS samples based on Jenike Flow

343 flow, while more difficult flow is indicated by lines lying near the top and the left of the graph;

344 flowability worsens as the flow function moves upwards in an anticlockwise direction (5). At

345 lower CDS levels $\left(10 \%\right.$, wb), for $100^{\circ} \mathrm{C}$, the flow function line lies near the shear stress axis (y-

346 axis), but for $200^{\circ} \mathrm{C}$ and $300^{\circ} \mathrm{C}$, it moves towards the normal stress axis (x-axis). This indicates

347 that DDGS with $10 \% \mathrm{CDS}$ level and dried at $100^{\circ} \mathrm{C}$ had a higher compressive strength, and thus

348 greater ability to obstruct flow (i.e., was least free flowing). But higher drying temperatures (200

349 and $\left.300^{\circ} \mathrm{C}\right)$ yielded better flowing DDGS with the same CDS level (10\%, wb). For higher CDS

350 levels (15 and 20\%, wb), a shift in the flow function line towards the x-axis was observed,

351 indicating better flowability, especially for the $200^{\circ} \mathrm{C}$ and $300^{\circ} \mathrm{C}$ drying temperatures. Generally,

352 higher CDS levels will result in higher fat content among the DDGS particles, which may hinder

353 flow, by forming bridges (i.e., molten or solidified fat layers) between particles, depending upon

354 temperature. In this study, there were slight shifts of the flow function lines towards the x-axis,

355 indicating better flow instead of flow obstruction. In some instances it has been found that higher

356 CDS levels in DDGS may lubricate the materials and create easy flow (5). For all 3 CDS levels,

357 the drying temperature showed similar behavior; higher temperature yielded better Jenike Flow

358 Function Index line mostly inclined to x-axis, indicating good flow.

359 Effect of Drying Temperature and CDS Levels on Particle Size and Bulk Density 
Figure 3 shows the effect of drying temperature on particle size and aerated bulk density

361 of the DDGS samples for different CDS addition levels. With an increase in the drying

362 temperature from 100 to $300^{\circ} \mathrm{C}$ the bulk density slightly increased as did particle size, except for

$36320 \%(\mathrm{wb}) \mathrm{CDS}$, where a decrease in the particle size from 100 to $200^{\circ} \mathrm{C}$ was observed. There

364 were also significant interactions between drying temperature and CDS (Table 3), thus the trend

365 observed in particle size is not solely due to the main effect of drying temperature alone, but

366 CDS and drying temperature together. These changes in particle size (due to the rapid formation

367 of dried layers on the particle surfaces) with drying temperature were similar to findings by

368 Chegini and Ghobadian (39). The particle size increase could be due to case hardening of the

369 droplets at the higher temperatures, which leads to the formation of vapor-impermeable films on

370 the drop surface, followed by the formation of vapor bubbles, and consequently droplet

371 expansion. This hardened skin does not allow the moisture to exit from the droplet, and as a

372 consequence the particle size is increases (39).

373 In terms of flowability, particle size plays an important role in the compressibility of

374 powders. An increase in the particle size can lead to a reduction in the bulk density of the

375 material, due to more entrapped void spaces (40) ${ }^{\text {but }}$ for our samples, the bulk density slightly

376 increased. This is may be due to the fact that increase in the particle size increased the mass of

377 the solid, which was due to CDS. Thus, the overall bulk density increased. Lower particle sizes

378 yield greater cohesive strength due to an increase in the surface/volume ratio between the

379 particles (41). Thus, again from the particle size and bulk density perspective, similar results: the

380 flowability was better with an increase in the drying temperatures at each CDS level, was

381 noticed.

382 Effect of Drying Temperature and CDS Levels on Protein Dispersibility Index (PDI) 
Protein Dispersibility Index estimates of the amount of water-soluble protein present in

384 the sample. From Figure 4, a decrease in the PDI with an increase in the drying temperature for each CDS level was observed. Regression equations with $\mathrm{R}^{2}$ values from 0.70 to 0.79 were obtained for all treatment combinations. Similar results of a decrease in PDI with an increase in 387 processing temperature were obtained by Thomas et al., (42) and Qin et al., (43). In Thomas et al., (42) the decrease in PDI was linear with an increase in temperature for soy grits, similar to what was found in DDGS. But for Qin et al., (43) the decrease in PDI was exponential for fullfat soybeans collected from different origins. The decrease in PDI is due to the fact that at higher temperatures, the denaturation of protein occurs, and hence it changes the protein's biochemical and solubility properties. It was observed that heat processed soy flour had lower PDI values, but high nutritional content, and high consumption and marketability (44).

395 facilitate the formation of hydrogen bonds with the associated moisture film present between the 396 particles, thus facilitating liquid bridging among particles. Increasing the drying temperature led 397 to greater denaturing of the protein, which in turn reduced the water-soluble side chains and 398 hence lowered PDI. But from a flowability perspective, lower PDI may mean a lower propensity 399 to form liquid bridges, and hence, less particle caking..

400 Effect of Drying Temperature and CDS Levels on Flowability Indicator ( $\zeta)$

$401 \quad$ Figure 5 indicates the relationships between drying temperature and CDS addition levels 402 with the "flowability indicator" parameter, $\zeta$. This parameter was developed by Ganesan et al. 403 (5), who established a predictive model for DDGS flowability based on combining Jenike and 404 Carr data using Exploratory Data Analysis techniques: 
or

408

$$
\zeta=\frac{C c}{\text { Dispersibility }} \times \frac{\delta}{\Phi}
$$

409

410 Where, $\mathrm{C}_{\mathrm{c}}$ represents Carr compressibility, $\delta$ represents the effective angle of friction, and $\Phi$ 411 represents the angle of internal friction. Generally, it has been found that lower regions in a

412 flowability indicator plot indicate good flow. In Ganesan et al., (5) the flowability indicator plot 413 for varying CDS and moisture contents resulted in a power law fit of $\mathrm{R}^{2}=0.94$. For this study, 414 higher drying temperature treatments occupied a position towards the origin of the plot, 415 indicating better flow for those treatments. For $15 \%$ (wb) CDS addition levels, an $\mathrm{R}^{2}$ value of 4160.90 was obtained, but for $10 \%$ and $20 \%$ CDS levels, high $\mathrm{R}^{2}$ values were not observed with a 417 power law regression model. Similar results were obtained when fitting exponential regression 418 equations to the data set, as indicated in Figure 6. Overall, the lower the drying temperature, the 419 worse the DDGS flowability.

\section{Regression Modeling and Multivariate Analysis}

421 Table 5 provides regression output for various combinations of physical and flow 422 properties, and provides predictive models for flowability parameters as functions of drying 423 temperature and CDS levels. The ratio of Total Flow Index/Jenike Flow Function Index (-) 424 yielded the highest $\mathrm{R}^{2}$ (0.943), whereas the ratio of Total Flow Index/Total Flood Index (-) yields 425 a slightly lower $\mathrm{R}^{2}(0.920)$, but has the lowest standard error value (0.031). Thus, from a 426 standard error point of view, Total Flow Index/Total Floodability Index $=f$ (drying temperature, 427 CDS levels) resulted in a better model for flowability than the Total Flow Index/Jenike Flow 428 Function Index $=f$ (drying temperature, CDS levels). 
Both of these new response variables are dimensionless, and therefore yield versatile

430 models for DDGS flowability. Additionally, these dimensionless parameters can overcome

431 limitations imposed by the units. Techniques for combining two or more properties with similar

432 units in order to achieve dimensionless parameters are often used in dimensional analysis and

433 Exploratory Data Analysis (EDA) (21). Extensive work by others regarding flowability

434 examined the dimensionless parameter $\zeta$ (equation 2 ), and obtained an $\mathrm{R}^{2}$ value of about 0.92

435 (21). However, for our case, $R^{2}=0.64$ was obtained, as indicated in Table 5. Angle of repose $\left(R^{2}\right.$

$436=0.88)$ and Jenike Flow Function Index $\left(R^{2}=0.80\right)$ yielded a better prediction of flowability

437 than $\zeta$. The Hausner Ratio, which is often used as a robust parameter to describe flowability, did

438 not give promising results in this study, with $\mathrm{R}^{2}=0.601$.

439 Response surface plots for AoR, HR, $\zeta$, Jenike Flow Function, Total Flow Index/Jenike

440 Flow Function, and Total Flow Index/Total Flood Index as functions of drying temperature and

441 CDS levels are provided in Figures 7 through 12. For "good" flow behavior in DDGS, it was

442 predicted that the ratio of Total Flow Index/Total Flood Index (-) should be from 1.25 to 1.29,

443 which indicates that drying temperature should be $>225^{\circ} \mathrm{C}$ and $\mathrm{CDS}<14 \%$ (wb) or $>17.5 \%$ (wb)

444 (Figure 11). Perhaps higher CDS levels $(>17.5 \%$, wb) lubricates the material and produces better

445 DDGS flow. Additionally, for "good" flow behavior in DDGS, it was predicted that the ratio of

446 Total Flow Index/Jenike Flow Index (-) should be from 22.50 to 24.50, which means that the

447 drying temperature should be between 200 to $260^{\circ} \mathrm{C}$ and $\mathrm{CDS}<14 \%$ (wb) (Figure 12).

448 Another way to look at the data is by multivariate analysis. Figure 13a and Figure 13b

449 represent the loading plot and model selection plot obtained from Partial Least Squares (PLS)

450 regression for Jenike Flow Function Index as a function of all physical and flow variables, as

451 listed in Table 1. Simple correlations between the original and the new variables are called the 
452 "loadings," and they indicate to what extent the original variables are influential in forming the 453 new set of Principal Components. In other words, the higher the loading value of the variable, 454 the more influential it is in forming the principal component scores.

455 Table 6 presents the summary results for the PLS regression modeling of Jenike Flow

456 Index as a function of all other properties. It was observed that a high $\mathrm{R}^{2}$ value of 0.90 using only

4572 components was possible. Jenike Flow Index can easily be calculated from linear regression

458 modeling whose coefficients are listed in Table 6. Therefore, the labor intensive task of the

459 Jenike shear test procedure could be avoided.

460 From Figure 13a, for 2 components only, AoS, Compressibility, Total Flow Index,

461 Hausner Ratio, and water activity were the variables which most influenced Jenike Flow Index.

462 Figure $13 \mathrm{~b}$ indicates $\mathrm{R}^{2}=0.9$ using two principal components only, although 6 components

463 resulted in an $\mathrm{R}^{2}$ of nearly 0.97 . Our experimental design had 26 dependent variables and 2

464 independent variables. PLS regression was found to be effective in reducing the

465 multidimensional dataset to a fewer number of components without loss of information (45).

\section{CONCLUSIONS}

470 Function, PDI, and $\zeta$ (a dimensionless flowability indicator) showed better flowability at higher

471 drying temperatures. Also, at higher drying temperatures, fewer significant differences were

472 observed in the flow and physical parameters among the CDS levels. Non-linear regression

473 analyses developed with dimensionless flowability parameters resulted in $\mathrm{R}^{2}>0.90$, and

474 adequately represented the effects of CDS and drying temperature. Partial Least Squares (PLS)

475 regression could effectively summarize the data with only two components, and provided a 
model for predicting Jenike Flow Index (-) as a function of all other flow and physical

477 parameters. Thus, future flowability studies may be able to avoid performing the labor-intensive

478 Jenike shear tests. Further studies with a larger sample size and more elaborate drying

479 temperatures and CDS addition levels should be investigated. Additional studies to quantify

480 flowability changes with varying cooling temperatures and times during storage should also be

481 pursued in order to more fully understand DDGS flowability behavior.

482

483

484

485

486

487

488

489

490

491

492

493

494

495

496

497

498

499

500

501

502

503

\section{ACKNOWLEDGEMENTS}

The authors would like to extend their gratitude to South Dakota State University and USDAARS for financial support, equipment, and facilities for this project. We would like to thank

Dakota Ethanol, LLC (Wentworth, SD) for contributing the coproduct samples for this study.

The authors would also like to extend appreciation for financial support to the South Dakota

Corn Utilization Council (SDCUC) and Agricultural Experimental Station (AES) as well.

\section{REFERENCES}

1. Chevanan, N.; Rosentrater K.A.; Muthukumarappan, K. Effect of DDGS, moisture content, and screw speed on physical properties of extrudates in single screw extrusion. Cereal Chemistry 2008, 85(2), 132-139.

2. AAFC: Protein meal: Situation and outlook. In Agriculture and Agri-Food Canada, Bi Weekly Bulletin, 2008; 19(3): 1-4. http://dsp-psd.pwgsc.gc.ca/Collection/A27-18-193E.pdf. Accessed on 14 October, 2011.

3. Bhadra, R.; Muthukumarappan, K.; Rosentrater, K.A. Flowability properties of commercial distillers dried grains with solubles. Cereal Chemistry 2009a, 86(2), 170-180.

4. Bhadra, R.; Rosentrater, K.A.; Muthukumarappan, K. Cross-sectional staining and surface properties of DDGS particles and their influence on the flowability. Cereal Chemistry 2009b, 86(4), 410-420. 
5. Ganesan, V.; Rosentrater, K.A.; Muthukumarappan, K. Physical and flow properties of regular and reduced fat distillers dried grains with solubles (DDGS). Food and Bioprocess Technology 2007a, 2(2), 156-166.

6. Rock, M.; Schwedes, J. Investigations on the caking behaviour of bulk solids-macroscale experiments. Powder Technology 2005, 157(1-3), 121-127.

7. Cruz, C.R..; Brouk, M.J.; Schingoethe, D.J. Lactational response of cows fed condensed corn distillers solubles. Dairy Science 2005, 88(11), 4000-4006.

8. Rosentrater, K.A.; Muthukumarappan, K. Corn ethanol coproducts: generation, properties, and future prospects. International Sugar Journal 2006, 108(1295), 648-657.

9. Werner, S.L.R.; Fanshawe, R.L.; Paterson, A.H.J.; Jones, J.R.; Pearce, D.L. Stickiness of corn syrup powders by fluidized bed test. International Journal of Food Engineering 2006, 2(5), $1-10$.

10. Ozkan, N.; Walisinghe, N.; Chen, X.D. Characterization of stickiness and cake formation in whole and skim milk powders. Food Engineering 2002, 55(4), 293-303.

11. Bronlund, J. Caking of spray dried lactose powders. PhD dissertation. Massey University; Auckland, New Zealand, 1996.

12. Shukla, P.R. Heat and mass transfer in packed food powders in relation to lumping and caking. Fourth Year Research Project; Department of Chemical and Materials Engineering. The University of Auckland; New Zealand, 2000. http://www.aiaa.org/agenda.cfm?lumeetingid=1188. Accessed on 14 October 2011.

13. Downton, G.E.; Flores-Lune, J.L.; King, C.J. Mechanism of stickiness in hydroscopic, amorphous powders. Industrial Engineering and Chemical Fundamentals 1982, 21(4), 447-451.

14. Wallack, D.A.; King, C., Sticking and agglomeration of hygroscopic, amorphous carbohydrate and food powders. Biotechnology Progress 1998, 4(1), 31-35.

15. Carr, R.L., Jr. Evaluating flow properties of solids. Chemical Engineering 1965, 72(3), 163-168.

16. Jenike, A.W. Storage and flow of solids. Bulletin No. 123. Utah Engineering Station; University of Utah; Salt Lake City, UT. 1964.

17. Michael, A.E. Pharmaceutics: The Science of Dosage Form Design ( $2^{\text {nd }}$ edition$)$; Churchill; Livingstone, UK, 2001.

18. Schulze, D. Storage of powders and bulk solids in silos, 2006. http://www.dietmerschulze.de/storagepr.html. Accessed on 14 October, 2011.

19. Ganesan, V.; Muthukumarappan, K.; Rosentrater, K.A. Flow properties of DDGS with varying soluble and moisture contents using Jenike shear testing. Powder Technology 2008a, 187(2), 130-137.

20. Ganesan, V.; Muthukumarappan, K. Rosentrater, K.A. Effect of flow agent addition on the physical properties of DDGS with varying moisture content and soluble levels. Transactions of ASABE 2008b, 51(2), 591-601. 
543 21. Ganesan, V.; Rosentrater, K.A.; Muthukumarappan, K. Modeling the flow properties of 544 distillers dried grains with solubles (DDGS). Cereal Chemistry 2007b, 84(6), 556-562.

545 22. Ganesan, V.; Rosentrater K.A.; Muthukumarappan, K. Dynamic water adsorption characteristics of distillers dried grains with solubles. Cereal Chemistry 2007c, 84(6), 584555.

23. Ganesan, V.; Muthukumarappan, K.; Rosentrater, K.A., Sorption isotherm characteristics of distillers dried grains with solubles (DDGS). Transactions of ASABE 2008c, 51(1), 169-176.

24. Bhadra, R.; Muthukumarappan, K.; Rosentrater, K.A. Physical and chemical characterization of fuel ethanol coproduct relevant to value-added uses. Cereal Chemistry 2010, 87(5), 439-447.

25. Bhadra, R.; Muthukumarappan, K.; Rosentrater, K.A.; Kannadhason, S. Drying characteristics of DWG with varying CDS and drying temperature levels. Applied Engineering in Agriculture 2009c, 27(5), 777-786.

26. Bhadra, R.; Rosentrater, K.A.; Muthukumarappan, K.; Kannadhason, S. Drying kinetics of DWG under varying CDS and temperature levels. Cereal Chemistry 2009d, 88(5), 451458.

27. Rosentrater, K.A. Some physical properties of DDGS. Applied Engineering in Agriculture 2006, 22(4), 589-595.

28. ASTM: Method D6393 Standard test method for bulk solids characterization by Carr indices; American Society for Testing and Materials; West Conshohocken, PA.1999.

29. Mohsenin, N.N. Physical Properties of Plant and Animal Materials ( $2^{\text {nd }}$ edition); Gordon and Breach Science Pub. Inc.; Amsterdam, Netherlands, 1986.

30. ASTM: Method D6128. Standard test method for shear testing of bulk solids using the Jenike Shear Cell; American Society for Testing and Materials; West Conshohocken, PA. 2006

31. ASTM: Method D6683 Standard test method for measuring bulk density values of powders and other bulk solids; American Society for Testing Materials; West Conshohocken, PA. 2001.

32. Baghe-Khandan, M.S.; Choi, Y.; Okos, M.R. Improved line heat source thermal conductivity probe. Food Science 1981, 46(5), 1430-1432.

33. ASAE: Standard S19.3 Method of determining and expressing fineness of feed materials by sieving; American Society of Agriculture Engineering Standards, Engineering Practices, Data; St Joseph, MI. 2003.

34. Sahin, S.; Sumnu, S.G. Physical Properties of Foods ( $1^{\text {st }}$ edition $)$; John Wiley and Sons; New York, NY, 1962.

35. AACC: Method 46-24. Protein dispersibility index; Approved Methods of American Association of Cereal Chemists, 10 ${ }^{\text {th }}$ edition; St Paul, MN. 1999. 
36. Carmer, S.G.; Swanson, M.R.; An evaluation of ten pairwise multiple comparison procedures by Monte Carlo method. American Statistical Association 1973, 68(341), 6674.

37. Speigel, M.R. Statistics ( $3^{\text {rd }}$ edition); McGraw Hill, Inc.; New York, NY, 1994.

38. Grey, R.O.; Beddow, J.K. On Hausner Ratio and its relationship to some properties of metal powders. Powder Technology 1969, 2(6), 323-326.

39. Chegini, G.R.; Ghobadian, B. Spray dryer parameters for fruit juice drying. World Journal of Agricultural Science 2007, 3(2), 230-236.

40. Yan, H.; Barbosa-Canovas, G.V. Compression characteristics of agglomerated food powders. Effect of agglomerate size and water activity. Food Science and Technology International 1997, 3(5), 351-359.

41. Marinelli, J.; Carson, J.W. Solve solids flow problems in bins, hoppers, and feeders. Chemical Engineering Progress 1992, 88(5): 22-28.

42. Thomas, M.; Van Kol Edwin, M.R.A.H.; Tamminga, S.; Verstegen, M.W.A.; Van der Poel, A.F.B. Effect of water, steam and shear conditioning on the protein quality of soy grits. Science of Food and Agriculture 1997, 74(3), 392-400.

43. Qin, G.X.; Verstegen, M.W.A.; Van der Poel, A.F.B. Effect of temperature and time during steam treatment on the protein quality of full fat soybean from different origins. Science of Food and Agriculture 1998, 77(3), 393-398.

44. Chell, M. Properties and food applications of soy flours (T. H. Applewhite (ed): The American Oil Chemists Society). In Proceedings of World Conference on Oilseed Technology Utilization, Urbana, IL, September 13-18, 1992; 306-313.

45. Sharma, S. Applied Multivariate Techniques (1st edition); John Wiley and Sons; New York, NY, 1996.

46. Zhang, C. H; Huang, L. X; Wang, C. P.; Mujumdar, A. S. Experimental and numerical investigation of spray-drying parameters on the dried powder properties of ginkgo biloba seeds. Drying Technology 2010, 28(3), 380-388.

47. Kurozawa, L. E.; Morassi, A. G.; Vanzo, A. A.; Park, K. J.; Hubinger, M. D. Influence of spray drying conditions on physicochemical properties of chicken meat powder. Drying Technology, 2009, 27(11), 1248-1257.

48. Jiang, J.; Lu, J.; Huang, R.; Li, X. Effects of time and temperature on the viscoelastic properties of Chinese fir wood. Drying Technology, 2009, 27(11), 1229-1234.

49. Witrowa-Rajchert, D.; Rząca, M. Effect of drying method on the microstructure and physical properties of dried apples. Drying Technology, 2009, 27(7/8), 903-909. 

properties of DDGS.*

\begin{tabular}{|c|c|c|c|c|c|c|}
\hline \multirow[b]{2}{*}{ Properties } & \multicolumn{3}{|c|}{ Temperature $\left({ }^{\circ} \mathbf{C}\right)$} & \multicolumn{3}{|c|}{ CDS (\% wb) } \\
\hline & 100 & 200 & 300 & 10 & 15 & 20 \\
\hline Angle of Repose $\left(^{\circ}\right)$ & $\begin{array}{c}44.47 b \\
(0.35)\end{array}$ & $\begin{array}{l}44.86 \mathrm{~b} \\
(0.71)\end{array}$ & $\begin{array}{c}46.36 \mathrm{a} \\
(0.56)\end{array}$ & $\begin{array}{l}42.86 \mathrm{c} \\
(0.07)\end{array}$ & $\begin{array}{c}45.69 \mathrm{~b} \\
(1.10)\end{array}$ & $\begin{array}{l}47.12 \mathrm{a} \\
(1.32)\end{array}$ \\
\hline Hausner Ratio (-) & $\begin{array}{l}1.17 \mathrm{a} \\
(0.01)\end{array}$ & $\begin{array}{l}1.15 \mathrm{a} \\
(0.01)\end{array}$ & $\begin{array}{l}1.09 \mathrm{~b} \\
(0.03)\end{array}$ & $\begin{array}{l}1.11 \mathrm{~b} \\
(0.07)\end{array}$ & $\begin{array}{l}1.14 a b \\
(0.02)\end{array}$ & $\begin{array}{l}1.15 \mathrm{a} \\
(1.00)\end{array}$ \\
\hline Carr Compressibility (\%) & $\begin{array}{l}14.71 \mathrm{a} \\
(3.53)\end{array}$ & $\begin{array}{l}12.80 \mathrm{a} \\
(2.56)\end{array}$ & $\begin{array}{l}7.88 \mathrm{~b} \\
(3.72)\end{array}$ & $\begin{array}{l}9.68 \mathrm{~b} \\
(2.71)\end{array}$ & $\begin{array}{c}12.17 \mathrm{ab} \\
(2.13)\end{array}$ & $\begin{array}{l}13.54 \mathrm{a} \\
(1.73)\end{array}$ \\
\hline Angle of Spatula $\left({ }^{\circ}\right)$ & $\begin{array}{c}53.95 \mathrm{a} \\
(1.07)\end{array}$ & $\begin{array}{l}48.67 \mathrm{c} \\
(1.10)\end{array}$ & $\begin{array}{c}49.26 \mathrm{~b} \\
(0.97)\end{array}$ & $\begin{array}{l}50.21 \mathrm{c} \\
(1.21)\end{array}$ & $\begin{array}{c}50.96 a \\
(1.32)\end{array}$ & $\begin{array}{c}50.70 \mathrm{~b} \\
(1.10)\end{array}$ \\
\hline Uniformity (-) & $\begin{array}{l}2.26 a \\
(0.13)\end{array}$ & $\begin{array}{l}2.13 b \\
(0.01)\end{array}$ & $\begin{array}{l}1.86 \mathrm{c} \\
(0.01)\end{array}$ & $\begin{array}{l}2.34 \mathrm{a} \\
(0.11)\end{array}$ & $\begin{array}{l}2.05 b \\
(0.20)\end{array}$ & $\begin{array}{l}1.85 \mathrm{c} \\
(0.01)\end{array}$ \\
\hline Total Flow Index (-) & $\begin{array}{l}75.86 \mathrm{~b} \\
(3.15)\end{array}$ & $\begin{array}{l}74.83 b \\
(1.06)\end{array}$ & $\begin{array}{c}79.40 \mathrm{a} \\
(1.26)\end{array}$ & $\begin{array}{c}78.178 \mathrm{a} \\
(2.17)\end{array}$ & $\begin{array}{l}75.25 \mathrm{c} \\
(1.64)\end{array}$ & $\begin{array}{c}76.66 \mathrm{~b} \\
(1.72)\end{array}$ \\
\hline Angle of Fall $\left(^{\circ}\right)$ & $\begin{array}{c}41.27 \mathrm{a} \\
(2.17)\end{array}$ & $\begin{array}{c}39.49 \mathrm{a} \\
(1.93)\end{array}$ & $\begin{array}{c}38.90 \mathrm{a} \\
(2.00)\end{array}$ & $\begin{array}{c}40.96 a \\
(1.94)\end{array}$ & $\begin{array}{c}41.00 \mathrm{a} \\
(1.16)\end{array}$ & $\begin{array}{c}37.69 \mathrm{~b} \\
(1.15)\end{array}$ \\
\hline Angle of Difference $\left({ }^{\circ}\right)$ & $\begin{array}{l}3.19 \mathrm{~b} \\
(0.07)\end{array}$ & $\begin{array}{l}5.37 \mathrm{ba} \\
(0.41)\end{array}$ & $\begin{array}{l}7.46 \mathrm{a} \\
(0.32)\end{array}$ & $\begin{array}{l}1.89 \mathrm{c} \\
(0.55)\end{array}$ & $\begin{array}{l}4.69 \mathrm{~b} \\
(0.52)\end{array}$ & $\begin{array}{l}9.43 \mathrm{a} \\
(0.07)\end{array}$ \\
\hline Dispersibility (\%) & $\begin{array}{c}39.30 \mathrm{~b} \\
(5.32)\end{array}$ & $\begin{array}{c}52.38 \mathrm{a} \\
(4.73)\end{array}$ & $\begin{array}{c}47.88 \mathrm{a} \\
(4.62)\end{array}$ & $\begin{array}{l}36.81 \mathrm{c} \\
(4.84)\end{array}$ & $\begin{array}{c}64.07 \mathrm{a} \\
(3.70)\end{array}$ & $\begin{array}{c}38.66 \mathrm{~b} \\
(3.62)\end{array}$ \\
\hline Total Flood Index (-) & $\begin{array}{l}63.83 \mathrm{c} \\
(1.32)\end{array}$ & $\begin{array}{l}69.33 \mathrm{a} \\
(1.26)\end{array}$ & $\begin{array}{c}67.17 \mathrm{~b} \\
(2.17)\end{array}$ & $\begin{array}{l}62.67 \mathrm{c} \\
(2.07)\end{array}$ & $\begin{array}{c}69.83 a \\
(3.15)\end{array}$ & $\begin{array}{c}67.83 \mathrm{~b} \\
(3.02)\end{array}$ \\
\hline$\delta\left(^{\circ}\right)$ & $\begin{array}{c}34.44 a \\
(0.72)\end{array}$ & $\begin{array}{l}36.22 \mathrm{a} \\
(0.97)\end{array}$ & $\begin{array}{c}36.56 \mathrm{a} \\
(0.56)\end{array}$ & $\begin{array}{l}39.00 \mathrm{a} \\
(0.41)\end{array}$ & $\begin{array}{c}33.55 b \\
(0.31)\end{array}$ & $\begin{array}{c}34.66 \mathrm{~b} \\
(0.27)\end{array}$ \\
\hline$\Phi\left({ }^{\circ}\right)$ & $\begin{array}{l}19.66 \mathrm{~b} \\
(1.07)\end{array}$ & $\begin{array}{l}24.79 \mathrm{a} \\
(1.02)\end{array}$ & $\begin{array}{c}23.67 \mathrm{a} \\
(1.32)\end{array}$ & $\begin{array}{l}24.22 \mathrm{a} \\
(1.75)\end{array}$ & $\begin{array}{l}21.55 \mathrm{a} \\
(1.89)\end{array}$ & $\begin{array}{c}22.33 \mathrm{a} \\
(2.52)\end{array}$ \\
\hline$\sigma_{\mathrm{c}}(\mathrm{kPa})$ & $\begin{array}{c}21.57 \mathrm{a} \\
(0.65)\end{array}$ & $\begin{array}{l}17.98 b \\
(0.57)\end{array}$ & $\begin{array}{c}18.98 \mathrm{~b} \\
(0.41)\end{array}$ & $\begin{array}{l}18.63 \mathrm{~b} \\
(0.72)\end{array}$ & $\begin{array}{l}20.33 \mathrm{a} \\
(0.81)\end{array}$ & $\begin{array}{c}19.56 \mathrm{a} \\
(0.32)\end{array}$ \\
\hline$\sigma_{1}(\mathrm{kPa})$ & $\begin{array}{c}40.21 b \\
(2.13)\end{array}$ & $\begin{array}{l}47.24 \mathrm{a} \\
(2.13)\end{array}$ & $\begin{array}{c}36.87 \mathrm{c} \\
(1.72)\end{array}$ & $\begin{array}{l}42.00 \mathrm{a} \\
(1.42)\end{array}$ & $\begin{array}{l}42.54 \mathrm{a} \\
(1.37)\end{array}$ & $\begin{array}{c}39.77 \mathrm{~b} \\
(1.26)\end{array}$ \\
\hline Jenike Flow Function Index (-) & $\begin{array}{l}1.87 \mathrm{c} \\
(0.11)\end{array}$ & $\begin{array}{l}2.68 \mathrm{a} \\
(0.02)\end{array}$ & $\begin{array}{l}2.18 \mathrm{~b} \\
(0.31)\end{array}$ & $\begin{array}{l}2.58 \mathrm{a} \\
(0.25)\end{array}$ & $\begin{array}{l}2.09 b \\
(0.71)\end{array}$ & $\begin{array}{l}2.04 \mathrm{~b} \\
(0.81)\end{array}$ \\
\hline Jenike Compressibility $(1 / \mathrm{cm})$ & $\begin{array}{c}13.82 \mathrm{ab} \\
(3.71)\end{array}$ & $\begin{array}{l}9.54 \mathrm{~b} \\
(4.51)\end{array}$ & $\begin{array}{l}16.30 \mathrm{a} \\
(5.31)\end{array}$ & $\begin{array}{c}12.05 \mathrm{ba} \\
(4.07)\end{array}$ & $\begin{array}{l}9.85 \mathrm{~b} \\
(3.17)\end{array}$ & $\begin{array}{l}17.76 \mathrm{a} \\
(4.02)\end{array}$ \\
\hline Hunter L (-) & $\begin{array}{c}48.63 \mathrm{a} \\
(2.71)\end{array}$ & $\begin{array}{c}46.43 b \\
(1.35)\end{array}$ & $\begin{array}{c}43.87 \mathrm{c} \\
(1.42)\end{array}$ & $\begin{array}{l}45.51 \mathrm{a} \\
(3.15)\end{array}$ & $\begin{array}{c}47.53 b \\
(2.73)\end{array}$ & $\begin{array}{c}45.89 \mathrm{c} \\
(1.17)\end{array}$ \\
\hline Hunter a (-) & $\begin{array}{l}9.99 \mathrm{a} \\
(1.71)\end{array}$ & $\begin{array}{l}10.05 \mathrm{a} \\
(2.17)\end{array}$ & $\begin{array}{l}9.35 \mathrm{~b} \\
(2.34)\end{array}$ & $\begin{array}{l}9.74 \mathrm{a} \\
(3.17)\end{array}$ & $\begin{array}{l}9.63 \mathrm{a} \\
(3.07)\end{array}$ & $\begin{array}{c}10.01 \mathrm{~b} \\
(2.71)\end{array}$ \\
\hline Hunter b (-) & $\begin{array}{c}23.47 \mathrm{a} \\
(2.10)\end{array}$ & $\begin{array}{l}21.93 \mathrm{a} \\
(3.12)\end{array}$ & $\begin{array}{c}20.61 \mathrm{c} \\
(2.17)\end{array}$ & $\begin{array}{l}21.91 \mathrm{a} \\
(3.02)\end{array}$ & $\begin{array}{c}22.38 \mathrm{~b} \\
(3.17)\end{array}$ & $\begin{array}{c}21.69 \mathrm{c} \\
(1.36)\end{array}$ \\
\hline$a_{w}(-)$ & $\begin{array}{l}0.68 \mathrm{a} \\
(3.51)\end{array}$ & $\begin{array}{l}0.44 \mathrm{~b} \\
(3.15)\end{array}$ & $\begin{array}{l}0.28 \mathrm{c} \\
(2.00)\end{array}$ & $\begin{array}{l}0.40 \mathrm{c} \\
(1.71)\end{array}$ & $\begin{array}{l}0.47 \mathrm{~b} \\
(3.02)\end{array}$ & $\begin{array}{l}0.52 \mathrm{a} \\
(1.71)\end{array}$ \\
\hline Thermal Conductivity $\left(\mathrm{W} /\left((\mathrm{m})\left({ }^{\circ} \mathrm{C}\right)\right)\right.$ & $\begin{array}{l}0.06 \mathrm{~b} \\
(0.01)\end{array}$ & $\begin{array}{l}0.07 \mathrm{a} \\
(0.01)\end{array}$ & $\begin{array}{l}0.07 \mathrm{~b} \\
(0.02)\end{array}$ & $\begin{array}{l}0.06 \mathrm{~b} \\
(0.02)\end{array}$ & $\begin{array}{c}0.06 a b \\
(0.10)\end{array}$ & $\begin{array}{l}0.07 \mathrm{a} \\
(0.04)\end{array}$ \\
\hline Thermal Resistivity $\left((\mathrm{m})\left({ }^{\circ} \mathrm{C}\right) / \mathrm{W}\right)$ & $\begin{array}{l}16.54 \mathrm{a} \\
(0.02)\end{array}$ & $\begin{array}{l}15.06 \mathrm{~b} \\
(0.07)\end{array}$ & $\begin{array}{l}15.98 \mathrm{a} \\
(0.03)\end{array}$ & $\begin{array}{l}17.12 \mathrm{a} \\
(0.02)\end{array}$ & $\begin{array}{c}15.36 \mathrm{~b} \\
(0.03)\end{array}$ & $\begin{array}{c}15.08 \mathrm{~b} \\
(0.12)\end{array}$ \\
\hline Thermal Diffusivity $\left(\mathrm{mm}^{2} / \mathrm{s}\right)$ & $\begin{array}{l}0.17 \mathrm{a} \\
(0.01)\end{array}$ & $\begin{array}{l}0.15 b \\
(0.00)\end{array}$ & $\begin{array}{l}0.15 \mathrm{~b} \\
(0.01)\end{array}$ & $\begin{array}{l}0.17 \mathrm{a} \\
(0.01)\end{array}$ & $\begin{array}{l}0.15 b \\
(0.02)\end{array}$ & $\begin{array}{l}0.15 b \\
(0.00)\end{array}$ \\
\hline Geometric Mean Diameter (mm) & $\begin{array}{l}0.73 b \\
(0.01)\end{array}$ & $\begin{array}{l}0.78 b \\
(0.51)\end{array}$ & $\begin{array}{l}0.99 \mathrm{a} \\
(0.42)\end{array}$ & $\begin{array}{l}0.91 \mathrm{a} \\
(0.21)\end{array}$ & $\begin{array}{l}0.75 b \\
(0.21)\end{array}$ & $\begin{array}{c}0.83 \mathrm{ab} \\
(0.31)\end{array}$ \\
\hline Porosity (-) & $\begin{array}{l}0.58 \mathrm{a} \\
(2.13)\end{array}$ & $\begin{array}{l}0.47 b \\
(3.17)\end{array}$ & $\begin{array}{l}0.47 \mathrm{~b} \\
(1.51)\end{array}$ & $\begin{array}{l}0.54 \mathrm{a} \\
(2.17)\end{array}$ & $\begin{array}{l}0.51 \mathrm{~b} \\
(2.07)\end{array}$ & $\begin{array}{l}0.46 \mathrm{c} \\
(1.91)\end{array}$ \\
\hline PDI $(\%)$ & $\begin{array}{c}9.3 \mathrm{a} \\
(2.11)\end{array}$ & $\begin{array}{l}7.61 \mathrm{~b} \\
(1.45)\end{array}$ & $\begin{array}{l}7.21 \mathrm{~b} \\
(3.02)\end{array}$ & $\begin{array}{l}8.33 \mathrm{a} \\
(0.89)\end{array}$ & $\begin{array}{l}7.59 b \\
(1.02)\end{array}$ & $\begin{array}{r}8.19 \mathrm{a} \\
(1.50)\end{array}$ \\
\hline
\end{tabular}

* Values with differing letters within a given row for a given independent variable are significantly different ( $<<0.05$, LSD); values in parentheses indicate \pm 1 standard deviation; CDS is condensed distillers solubles $(\%, w b) ; \delta$ is effective angle of internal friction $\left(^{\circ}\right)$; $\Phi$ is angle of internal friction $\left({ }^{\circ}\right) ; \sigma_{\mathrm{c}}$ is unconfined yield strength $(\mathrm{kPa}) ; \sigma_{1}$ is major consolidation stress $(\mathrm{kPa}) ; \mathrm{a}_{\mathrm{w}}$ is water activity $(-)$; PDI is protein dispersibility index $(\%)$. 
Table 2: Interaction effects (p-values) of drying temperature and CDS levels on resulting flow and physical properties of DDGS.*

\begin{tabular}{lccc}
\hline Properties & Temperature $\left({ }^{\circ} \mathbf{C}\right)$ & CDS $(\%$ wb $)$ & CDS*Temp \\
\hline Angle of Repose $\left({ }^{\circ}\right)$ & $<0.0001$ & $<0.0001$ & 0.0003 \\
Hausner Ratio $(-)$ & 0.0004 & 0.0344 & 0.2664 \\
Carr Compressibility $(\%)$ & 0.0003 & 0.033 & 0.2766 \\
Angle of Spatula $\left({ }^{\circ}\right)$ & $<0.0001$ & $<0.0001$ & $<0.0001$ \\
Uniformity $(-)$ & $<0.0001$ & $<0.0001$ & $<0.0001$ \\
Total Flow Index $(-)$ & $<0.0001$ & $<0.0001$ & $<0.0001$ \\
Angle of Fall $\left({ }^{\circ}\right)$ & $<0.0001$ & $<0.0001$ & $<0.0001$ \\
Angle of Difference $\left({ }^{\circ}\right)$ & $<0.0001$ & $<0.0001$ & $<0.0001$ \\
Dispersibility $(\%)$ & $<0.0001$ & $<0.0001$ & $<0.0001$ \\
Total Flood Index $(-)$ & $<0.0001$ & $<0.0001$ & $<0.0001$ \\
$\delta\left({ }^{\circ}\right)$ & 0.0362 & $<0.0001$ & $<0.0001$ \\
$\Phi\left(^{\circ}\right)$ & 0.0032 & 0.1519 & 0.0175 \\
$\sigma_{\mathrm{c}}(\mathrm{kPa})$ & $<0.0001$ & 0.003 & 0.0042 \\
$\sigma_{1}(\mathrm{kPa})$ & $<0.0001$ & 0.0002 & $<0.0001$ \\
Jenike Flow Function Index $(-)$ & $<0.0001$ & $<0.0001$ & $<0.0001$ \\
Jenike Compressibility $(1 / \mathrm{cm})$ & $<0.0001$ & $<0.0001$ & $<0.0001$ \\
Hunter L $(-)$ & $<0.0001$ & $<0.0001$ & $<0.0001$ \\
Hunter a $(-)$ & $<0.0012$ & 0.1158 & 0.0019 \\
Hunter b (-) & $<0.0001$ & 0.0871 & 0.0052 \\
$\mathrm{a}_{\mathrm{w}}(-)$ & $<0.0001$ & $<0.0001$ & $<0.0001$ \\
Thermal Conductivity $\left(\mathrm{W} /\left((\mathrm{m})\left({ }^{\circ} \mathrm{C}\right)\right)\right.$ & 0.0008 & 0.0221 & 0.0358 \\
Thermal Resistivity $\left((\mathrm{m})\left({ }^{\circ} \mathrm{C}\right) / \mathrm{W}\right)$ & $<0.0001$ & $<0.0001$ & $<0.0001$ \\
Thermal Diffusivity $\left.(\mathrm{mm})^{2} / \mathrm{s}\right)$ & $<0.0001$ & 0.004 \\
Geometric Mean Diameter $(\mathrm{mm})$ & $<0.0001$ & $<0.0001$ \\
Porosity $(-)$ & $<0.0001$ & 0.0176 \\
PDI $(\%)$ & 0.0006 & 0.0064 \\
\hline
\end{tabular}

* Values in the table are the p-values determined by PROC GLM using SAS, $<<0.05$; CDS is condensed distillers solubles (\%, wb); $\delta$ is effective angle of internal friction $\left({ }^{\circ}\right)$; $\Phi$ is angle of internal friction $\left({ }^{\circ}\right) ; \sigma_{\mathrm{c}}$ is unconfined yield strength $(\mathrm{kPa}) ; \sigma_{1}$ is major consolidation stress $(\mathrm{kPa})$; $\mathrm{a}_{\mathrm{w}}$ is water activity $(-)$; PDI is protein dispersibility index $(\%)$. 
Table 3: Treatment combination effects of drying temperature and CDS levels on resulting flow and physical properties of DDGS.*

\begin{tabular}{|c|c|c|c|c|c|c|c|c|c|}
\hline \multirow[b]{4}{*}{ Properties } & \multicolumn{9}{|c|}{ Temperature $\left({ }^{\circ} \mathrm{C}\right)$} \\
\hline & \multicolumn{3}{|c|}{100} & \multicolumn{3}{|c|}{200} & \multicolumn{3}{|c|}{300} \\
\hline & \multicolumn{3}{|c|}{ CDS (\% wb) } & \multicolumn{3}{|c|}{ CDS (\% wb) } & \multicolumn{3}{|c|}{ CDS (\% wb) } \\
\hline & 10 & 15 & 20 & 10 & 15 & 20 & 10 & 15 & 20 \\
\hline \multirow[t]{2}{*}{ Angle of Repose $\left(^{\circ}\right)$} & $42.06 \mathrm{c}$ & $44.71 b$ & $46.61 \mathrm{a}$ & $42.02 \mathrm{c}$ & $44.94 b$ & $47.62 \mathrm{a}$ & $44.55 c$ & $47.43 a$ & $47.14 b$ \\
\hline & $(0.42)$ & $(0.61)$ & $(0.51)$ & $(0.31)$ & $(0.25)$ & $(0.75)$ & $(0.44)$ & $(0.37)$ & $(0.31)$ \\
\hline \multirow[t]{2}{*}{ Hausner Ratio (-) } & $1.13 a$ & $1.19 a$ & $1.20 \mathrm{a}$ & $1.11 a$ & $1.15 a$ & 1.18a & $1.09 a$ & $1.07 a$ & $1.09 a$ \\
\hline & $(0.02)$ & $(0.07)$ & $(0.00)$ & (1.17) & $(1.21)$ & $(0.05)$ & $(1.03)$ & $(1.71)$ & $(1.21)$ \\
\hline \multirow[t]{2}{*}{ Carr Compressibility (\%) } & $11.28 \mathrm{a}$ & $15.85 a$ & $17.00 \mathrm{a}$ & $9.39 b$ & $13.55 \mathrm{ab}$ & $15.45 \mathrm{a}$ & 8.67a & $7.120 \mathrm{a}$ & $8.16 a$ \\
\hline & $(3.21)$ & $(2.71)$ & $(1.17)$ & $(3.12)$ & $(1.91)$ & $(1.71)$ & $(2.56)$ & $(1.71)$ & $(2.01)$ \\
\hline \multirow[t]{2}{*}{ Angle of Spatula $\left(^{\circ}\right)$} & $55.86 a$ & $53.50 \mathrm{~b}$ & $52.49 \mathrm{c}$ & $46.26 \mathrm{c}$ & $50.18 \mathrm{a}$ & $49.56 \mathrm{~b}$ & $48.51 \mathrm{c}$ & $49.20 \mathrm{~b}$ & $50.05 \mathrm{a}$ \\
\hline & $(1.07)$ & $(1.21)$ & $(1.11)$ & $(0.92)$ & $(2.17)$ & $(1.31)$ & $(0.91)$ & $(1.07)$ & $(1.03)$ \\
\hline \multirow[t]{2}{*}{ Uniformity (-) } & $2.53 \mathrm{a}$ & $2.00 \mathrm{~b}$ & $1.85 \mathrm{c}$ & $2.51 \mathrm{a}$ & $2.31 \mathrm{a}$ & $1.95 \mathrm{c}$ & $2.000 \mathrm{a}$ & $1.840 \mathrm{~b}$ & $1.75 \mathrm{c}$ \\
\hline & $(0.01)$ & $(0.21)$ & $(0.01)$ & $(0.31)$ & $(0.02)$ & $(0.01)$ & $(0.03)$ & $(0.21)$ & $(0.01)$ \\
\hline \multirow[t]{2}{*}{ Total Flow Index (-) } & $77.83 \mathrm{a}$ & $75.25 b$ & $74.50 \mathrm{c}$ & $78.50 \mathrm{a}$ & $74.50 \mathrm{~b}$ & $71.50 \mathrm{c}$ & $78.20 \mathrm{a}$ & $79.00 a$ & 81.00a \\
\hline & $(4.12)$ & $(2.17)$ & $(3.17)$ & $(2.72)$ & $(3.51)$ & $(2.16)$ & $(1.50)$ & $(1.42)$ & $(1.37)$ \\
\hline \multirow[t]{2}{*}{ Angle of Fall $\left(^{\circ}\right)$} & $39.87 \mathrm{c}$ & $40.75 b$ & $43.18 \mathrm{a}$ & $39.36 a$ & 39.750a & $39.36 a$ & $43.66 \mathrm{a}$ & $42.50 \mathrm{a}$ & $30.53 b$ \\
\hline & $(1.41)$ & $(1.37)$ & $(1.21)$ & $(1.06)$ & $(1.21)$ & $(1.03)$ & $(0.04)$ & $(0.51)$ & $(0.72)$ \\
\hline \multirow[t]{2}{*}{ Angle of Difference $\left(^{\circ}\right)$} & $2.19 b$ & $3.96 \mathrm{a}$ & $3.43 \mathrm{ab}$ & $2.66 \mathrm{c}$ & $5.193 b$ & $8.26 \mathrm{a}$ & $0.84 \mathrm{c}$ & $4.93 b$ & $16.60 \mathrm{a}$ \\
\hline & $(0.07)$ & $(0.09)$ & $(1.02)$ & $(0.06)$ & $(1.21)$ & (1.03) & $(0.04)$ & $(0.51)$ & $(0.72)$ \\
\hline Dispersibility (\%) & $41.70 \mathrm{~b}$ & $46.07 \mathrm{a}$ & $30.13 c$ & $34.16 \mathrm{c}$ & $73.40 \mathrm{a}$ & $49.57 \mathrm{~b}$ & $34.59 \mathrm{~b}$ & $72.75 a$ & $36.29 b$ \\
\hline & $(3.71)$ & $(4.02)$ & $(5.72)$ & $(4.62)$ & $(3.12)$ & $(2.17)$ & $(5.07)$ & $(4.31)$ & $(3.76)$ \\
\hline Total Flood Index (-) & $61.00 \mathrm{~b}$ & $70.00 \mathrm{a}$ & $60.50 \mathrm{c}$ & $65.50 \mathrm{c}$ & $70.00 \mathrm{~b}$ & $72.50 \mathrm{a}$ & $61.50 \mathrm{c}$ & $69.50 \mathrm{~b}$ & $70.50 \mathrm{a}$ \\
\hline & $(1.71)$ & $(2.07)$ & $(1.51)$ & $(1.32)$ & $(1.40)$ & $(0.91)$ & $(2.16)$ & $(1.73)$ & $(1.51)$ \\
\hline$\delta\left({ }^{\circ}\right)$ & $37.66 \mathrm{a}$ & $33.33 b$ & $32.33 b$ & $34.33 b$ & $35.33 b$ & $39.00 \mathrm{a}$ & $45.00 \mathrm{a}$ & $32.00 \mathrm{~b}$ & $32.66 \mathrm{~b}$ \\
\hline & $(0.45)$ & $(0.32)$ & $(0.21)$ & $(0.74)$ & $(0.51)$ & $(0.71)$ & $(0.64)$ & $(0.81)$ & $(1.02)$ \\
\hline$\Phi\left(^{\circ}\right)$ & $17.33 \mathrm{~b}$ & $21.66 \mathrm{a}$ & $20.00 \mathrm{ab}$ & $27.00 \mathrm{a}$ & $22.33 b$ & $25.00 \mathrm{a}$ & $28.33 a$ & $20.66 \mathrm{a}$ & $22.00 \mathrm{a}$ \\
\hline & $(1.01)$ & $(1.07)$ & $(1.21)$ & $(1.31)$ & $(0.75)$ & $(0.51)$ & $(1.72)$ & $(2.01)$ & $(2.31)$ \\
\hline$\sigma_{\mathrm{c}}(\mathrm{kPa})$ & $21.94 \mathrm{a}$ & $21.68 \mathrm{a}$ & $21.09 \mathrm{a}$ & $15.67 \mathrm{~b}$ & $19.93 \mathrm{a}$ & $18.32 \mathrm{a}$ & $18.27 \mathrm{a}$ & $19.39 \mathrm{a}$ & $19.28 \mathrm{a}$ \\
\hline & $(0.41)$ & $(0.21)$ & $(0.23)$ & $(0.71)$ & $(0.50)$ & $(1.51)$ & $(1.72)$ & $(1.63)$ & $(1.54)$ \\
\hline$\sigma_{1}(\mathrm{kPa})$ & $37.68 \mathrm{~b}$ & $42.13 \mathrm{a}$ & $40.81 \mathrm{a}$ & $53.22 \mathrm{a}$ & $45.91 b$ & $42.59 \mathrm{c}$ & $35.11 \mathrm{~b}$ & $39.58 \mathrm{a}$ & $35.91 b$ \\
\hline & $(1.71)$ & $(1.52)$ & $(1.31)$ & $(0.72)$ & $(0.56)$ & $(1.15)$ & $(1.72)$ & $(1.63)$ & $(1.54)$ \\
\hline Jenike Flow Function Index (-) & $1.72 \mathrm{~b}$ & $1.94 \mathrm{a}$ & $1.94 \mathrm{a}$ & $3.39 \mathrm{a}$ & $2.30 \mathrm{~b}$ & $2.33 \mathrm{~b}$ & $2.64 \mathrm{a}$ & $2.03 \mathrm{~b}$ & $1.86 \mathrm{c}$ \\
\hline & $(0.11)$ & $(0.02)$ & $(0.00)$ & $(0.31)$ & $(0.71)$ & $(0.31)$ & $(0.43)$ & $(0.500$ & $(0.37)$ \\
\hline Jenike Compressibility (1/cm) & $12.57 \mathrm{~b}$ & $7.10 \mathrm{c}$ & $21.79 \mathrm{a}$ & $2.19 \mathrm{~b}$ & $12.82 \mathrm{a}$ & $13.61 \mathrm{a}$ & $21.39 \mathrm{a}$ & $9.64 c$ & $17.87 \mathrm{~b}$ \\
\hline & $(4.12)$ & $(3.17)$ & $(2.71)$ & $(5.16)$ & $(5.01)$ & $(3.74)$ & $(3.02)$ & $(1.21)$ & $(1.94)$ \\
\hline Hunter L (-) & $46.22 \mathrm{c}$ & $51.72 \mathrm{a}$ & $47.94 \mathrm{~b}$ & $47.24 a$ & $46.67 a$ & 45.38a & $43.07 \mathrm{~b}$ & $44.18 \mathrm{a}$ & $44.36 \mathrm{a}$ \\
\hline & $(2.17)$ & $(1.23)$ & $(2.13)$ & $(1.93)$ & $(1.16)$ & $(1.53)$ & $(1.62)$ & $(2.10)$ & $(0.77)$ \\
\hline Hunter a (-) & $9.48 \mathrm{~b}$ & $9.80 \mathrm{ba}$ & $10.68 \mathrm{a}$ & $10.59 \mathrm{a}$ & $9.51 \mathrm{~b}$ & $10.03 \mathrm{ba}$ & $9.13 a$ & $9.59 \mathrm{a}$ & 9.32a \\
\hline & $(2.01)$ & $(1.71)$ & $(1.51)$ & (1.010 & $(0.09)$ & $(0.91)$ & $(0.72)$ & $(0.77)$ & $(0.73)$ \\
\hline Hunter b (-) & $22.94 \mathrm{ab}$ & $24.73 a$ & $22.73 b$ & $22.66 \mathrm{a}$ & $21.68 \mathrm{ab}$ & $21.45 b$ & $20.15 b$ & $20.75 a$ & $20.91 \mathrm{a}$ \\
\hline & $(2.13)$ & $(1.71)$ & $(1.63)$ & (1.63) & $(2.07)$ & $(0.17)$ & $(0.89)$ & $(1.31)$ & $(0.74)$ \\
\hline$a_{w}(-)$ & $0.64 \mathrm{c}$ & $0.68 b$ & $0.71 \mathrm{a}$ & $0.33 \mathrm{c}$ & $0.46 \mathrm{~b}$ & $0.54 \mathrm{a}$ & $0.23 \mathrm{c}$ & $0.28 b$ & $0.32 \mathrm{a}$ \\
\hline & $(0.71)$ & $(0.43)$ & $(0.06)$ & $(0.31)$ & $(0.21)$ & $(0.01)$ & $(1.20)$ & $(1.03)$ & $(0.17)$ \\
\hline Thermal Conductivity & & & & & & & & & \\
\hline$\left(\mathrm{W} /\left((\mathrm{m})\left({ }^{\circ} \mathrm{C}\right)\right)\right.$ & $0.06 \mathrm{~b}$ & $0.06 \mathrm{~b}$ & $0.07 \mathrm{a}$ & $0.07 a$ & $0.07 \mathbf{a}$ & $0.07 \mathbf{a}$ & $0.06 a$ & $0.07 a$ & $0.066 a$ \\
\hline & $(0.03)$ & $(0.31)$ & $(0.01)$ & $(0.02)$ & $(0.04)$ & $(0.05)$ & $(0.03)$ & $(0.01)$ & $(0.00)$ \\
\hline Thermal Resistivity $\left((\mathrm{m})\left({ }^{\circ} \mathrm{C}\right) / \mathrm{W}\right)$ & $17.86 \mathrm{a}$ & $16.73 b$ & $15.03 \mathrm{c}$ & $15.30 \mathrm{a}$ & $14.60 \mathrm{~b}$ & $15.26 \mathrm{a}$ & $18.20 \mathrm{a}$ & $14.76 \mathrm{~b}$ & $14.96 \mathrm{~b}$ \\
\hline & $(0.01)$ & $(0.01)$ & $(0.07)$ & $(0.06)$ & $(0.64)$ & $(0.05)$ & $(0.04)$ & $(0.06)$ & $(0.51)$ \\
\hline Thermal Diffusivity $\left(\mathrm{mm}^{2} / \mathrm{s}\right)$ & $0.18 \mathrm{a}$ & $0.173 \mathrm{a}$ & $0.16 b$ & $0.16 \mathrm{a}$ & $0.143 \mathrm{a}$ & $0.15 \mathrm{a}$ & $0.17 \mathrm{a}$ & $0.14 b$ & $0.14 b$ \\
\hline & $(0.01)$ & $(0.34)$ & $(0.07)$ & $(0.06)$ & $(0.17)$ & $(0.12)$ & $(0.51)$ & $(0.42)$ & $(0.31)$ \\
\hline Geometric Mean Diameter (mm) & $0.69 \mathrm{~b}$ & $0.67 \mathrm{c}$ & $0.82 \mathrm{a}$ & $0.72 \mathrm{c}$ & $0.79 \mathrm{~b}$ & $0.83 \mathrm{a}$ & $1.31 \mathrm{a}$ & $0.81 \mathrm{c}$ & $0.85 b$ \\
\hline & $(0.13)$ & $(0.71)$ & $(0.53)$ & $(0.07)$ & $(0.06)$ & $(0.51)$ & $(0.41)$ & $(0.31)$ & $(0.27)$ \\
\hline Porosity (-) & $0.61 \mathrm{a}$ & $0.57 \mathrm{~b}$ & $0.55 b$ & $0.49 \mathrm{a}$ & $0.49 \mathrm{a}$ & $0.43 \mathrm{~b}$ & $0.53 \mathrm{a}$ & $0.47 b$ & $0.42 \mathrm{c}$ \\
\hline & (1.37) & $(2.01)$ & (3.14) & (1.42) & $(2.15)$ & $(2.14)$ & $(1.71)$ & (1.62) & $1.06)$ \\
\hline PDI (\%) & $9.56 \mathrm{a}$ & $9.34 a$ & 8.98a & $8.10 \mathrm{a}$ & $6.85 \mathrm{~b}$ & $7.88 \mathrm{a}$ & $7.33 \mathrm{a}$ & $6.59 \mathrm{ab}$ & $7.71 \mathrm{a}$ \\
\hline & $(0.71)$ & $(1.45)$ & (3.51) & (1.03) & (3.12) & (4.02) & (3.140 & $(0.89)$ & $(0.93)$ \\
\hline
\end{tabular}

* Values with differing letters within a given row are significantly different ( $<0.05, \mathrm{LSD})$ across all treatment combinations; values in parentheses indicate \pm 1 standard deviation; bold numbers indicate values for which there were no significant differences amongst the CDS levels for a given drying temperature level. CDS is condensed distillers solubles $(\%, \mathrm{wb}) ; \delta$ is effective angle of internal friction $\left(^{\circ}\right) ; \Phi$ is angle of internal friction $\left(^{\circ}\right) ; \sigma_{\mathrm{c}}$ is unconfined yield strength $(\mathrm{kPa}) ; \sigma_{1}$ is major consolidation stress $(\mathrm{kPa}) ; \mathrm{a}_{\mathrm{w}}$ is water activity (-); PDI is protein dispersibility index (\%). 
Table 4: Pearson linear correlation coefficients ( $r$ ) between resulting flow and physical properties for DDGS prepared using varying drying temperature and CDS combinations. Only significant $(\mathbf{p}<\mathbf{0 . 0 5})$ correlations are listed*

\begin{tabular}{lcc}
\hline Variable combinations & r & p-value \\
\hline Thermal Conductivity $\times$ Temperature & -0.936 & $<0.0001$ \\
Angle of Difference $\times$ Angle of Fall & -0.889 & $<0.0001$ \\
Angle of Repose $\times$ Uniformity & -0.881 & $<0.0001$ \\
$\sigma_{1} \times$ Jenike Compressibility & -0.857 & $<0.0001$ \\
Temperature $\times \mathrm{a}_{\mathrm{w}}$ & -0.820 & $<0.0001$ \\
Jenike Compressibility $\times$ Angle of Spatula & -0.796 & $<0.0001$ \\
Temperature $\times$ Hunter a & -0.792 & $<0.0001$ \\
CDS $\times$ Uniformity & -0.736 & $<0.0001$ \\
Thermal Diffusivity $\times$ Thermal Resistivity & -0.716 & $<0.0001$ \\
Temperature $\times$ Angle of Spatula & -0.705 & $<0.0001$ \\
& & \\
Thermal Conductivity $\times$ Carr Compressibility & 0.705 & $<0.0001$ \\
Thermal Conductivity $\times$ Hunter a & 0.721 & $<0.0001$ \\
$\mathrm{a}_{\mathrm{w}} \times$ Thermal Conductivity & 0.736 & $<0.0001$ \\
PDI $\times$ Geometric Mean Diameter & 0.743 & $<0.0001$ \\
Thermal Conductivity $\times$ Angle of Spatula & 0.796 & $<0.0001$ \\
Thermal Diffusivity $\times$ Geometric Mean Diameter & 0.828 & $<0.0001$ \\
Hunter a $\times \mathrm{a}_{\mathrm{w}}$ & 0.852 & $<0.0001$ \\
$\sigma_{1} \times$ Angle of Spatula & 0.867 & $<0.0001$ \\
Hausner Ratio $\times$ Carr Compressibility & 0.998 & $<0.0001$ \\
\hline
\end{tabular}

* CDS is condensed distillers solubles level $(\%, w b) ; \sigma_{1}$ is major consolidation stress $(\mathrm{kPa})$; $\mathrm{a}_{\mathrm{w}}$ is water activity (-); PDI is protein dispersibility index (\%). 
Table 5: Prediction models for selected dependent variables developed by response surface regression.*

\begin{tabular}{|c|c|c|c|c|c|c|c|}
\hline \multicolumn{2}{|c|}{ Dependent Variable } & $\mathbf{A O R}(-)$ & HR (-) & Jenike Flow Function Index (-) & $\zeta(-)$ & Total Flow Index/Total Flood Index (-) & Total Flow Index/Jenike Flow Function Index (-) \\
\hline & $\mathrm{x}$ & Temperature & Temperature & Temperature & Temperature & Temperature & Temperature \\
\hline \multicolumn{2}{|c|}{ Independent Variable } & CDS & CDS & CDS & CDS & CDS & CDS \\
\hline \multicolumn{2}{|c|}{ Prediction Equation } & $\mathrm{z}=\mathrm{a}+\mathrm{bx} \mathrm{x}^{3}+\mathrm{c} / \mathrm{y}$ & $z^{-1}=a+b x^{3}+c / y$ & $z^{-1}=a+b / \ln x+c / x^{0.5}+d \ln y+e / l n y$ & $z=a+b / x+c y^{3}$ & $z=\left(a+b x+c x^{2}+d \ln y\right) /\left(1+e x+f x^{2}+g \ln y+h(\ln y)^{2}\right)$ & $\mathrm{z}=\mathrm{a}+\mathrm{b} \ln x+\mathrm{c} / \mathrm{y}+\mathrm{d}(\ln x)^{2}+\mathrm{e} / \mathrm{y}^{2}+\mathrm{f}(\ln \mathrm{n}) / \mathrm{y}$ \\
\hline \multirow{4}{*}{$\begin{array}{l}\text { Model } \\
\text { Performance }\end{array}$} & $\mathrm{R}^{2}$ & 0.881 & 0.601 & 0.804 & 0.643 & 0.920 & 0.943 \\
\hline & Adjusted $\mathrm{R}^{2}$ & 0.865 & 0.549 & 0.757 & 0.596 & 0.884 & 0.926 \\
\hline & F statistic & 88.733 & 18.091 & 22.512 & 21.610 & 31.096 & 69.793 \\
\hline & Standard error & 0.760 & 0.037 & 0.242 & 0.142 & 0.031 & 1.858 \\
\hline \multirow{8}{*}{$\begin{array}{l}\text { Model } \\
\text { Parameters }\end{array}$} & a & $5.05 \mathrm{E}+01$ & $7.89 \mathrm{E}-01$ & $2.60 \mathrm{E}+01$ & $-9.37 \mathrm{E}-03$ & $-9.73 \mathrm{E}-01$ & $8.38 \mathrm{E}+02$ \\
\hline & b & $7.39 \mathrm{E}-08$ & 2.63E-09 & $-1.77 \mathrm{E}+02$ & $5.85 \mathrm{E}+01$ & $-2.98 \mathrm{E}-03$ & $-3.36 \mathrm{E}+02$ \\
\hline & c & $-8.52 \mathrm{E}+01$ & $8.08 \mathrm{E}-01$ & $1.76 \mathrm{E}+02$ & $2.44 \mathrm{E}-05$ & $6.17 \mathrm{E}-06$ & $1.92 \mathrm{E}+03$ \\
\hline & d & & & $-8.16 \mathrm{E}-01$ & & $3.76 \mathrm{E}-01$ & $3.51 \mathrm{E}+01$ \\
\hline & $\mathrm{e}$ & & & $-6.77 E+00$ & & $-3.44 \mathrm{E}-03$ & $1.08 \mathrm{E}+02$ \\
\hline & $\mathrm{f}$ & & & & & $7.53 \mathrm{E}-06$ & $-3.93 \mathrm{E}+02$ \\
\hline & $\mathrm{g}$ & & & & & $-9.81 \mathrm{E}-01$ & \\
\hline & $\mathrm{h}$ & & & & & $2.38 \mathrm{E}-01$ & \\
\hline Figure No. & & 7 & 8 & 9 & 10 & 11 & 12 \\
\hline
\end{tabular}

* AoR is angle of repose $\left(^{\circ}\right)$; HR is Hausner Ratio (-); CDS is condensed distillers solubles level $(\% \mathrm{wb})$; $\zeta$ is an empirical flowability indicator defined as $=\left(\mathrm{C}_{\mathrm{c}} / \text { Dispersibility }\right)^{*}(\delta / \Phi){ }^{\prime} \mathrm{Ganesan}$ et al.,

2007b). Each equation is plotted in the denoted figure. 
Table 6. Partial Least Squares (PLS) regression results for Jenike Flow Function Index (-) as a multivariate function of all other flow and physical properties (excluding the Jenike properties).

\begin{tabular}{lc}
\hline Predictor Variables & Parameter Estimates \\
\hline Constant & 9.6106 \\
Angle of Repose & -0.0817 \\
Hausner Ratio & 0.2675 \\
Compressibility & 0.0036 \\
Angle of Spatula & -0.1203 \\
Uniformity & 0.2858 \\
Total Flow Index & -0.0100 \\
Angle of Fall & 0.0145 \\
Angle of Difference & -0.0272 \\
Dispersibility & -0.0115 \\
Total Flood Index & 0.0301 \\
Water Activity & -0.2967 \\
Thermal Conductivity & 12.4430 \\
Thermal Diffusivity & -0.9390 \\
Geometric Mean Diameter & 0.0266 \\
Porosity & -0.4575 \\
\hline R & 0.90 \\
p-Value & 0.0001 \\
F Statistic & 100.39 \\
PLS Components Required & 2 \\
\hline
\end{tabular}



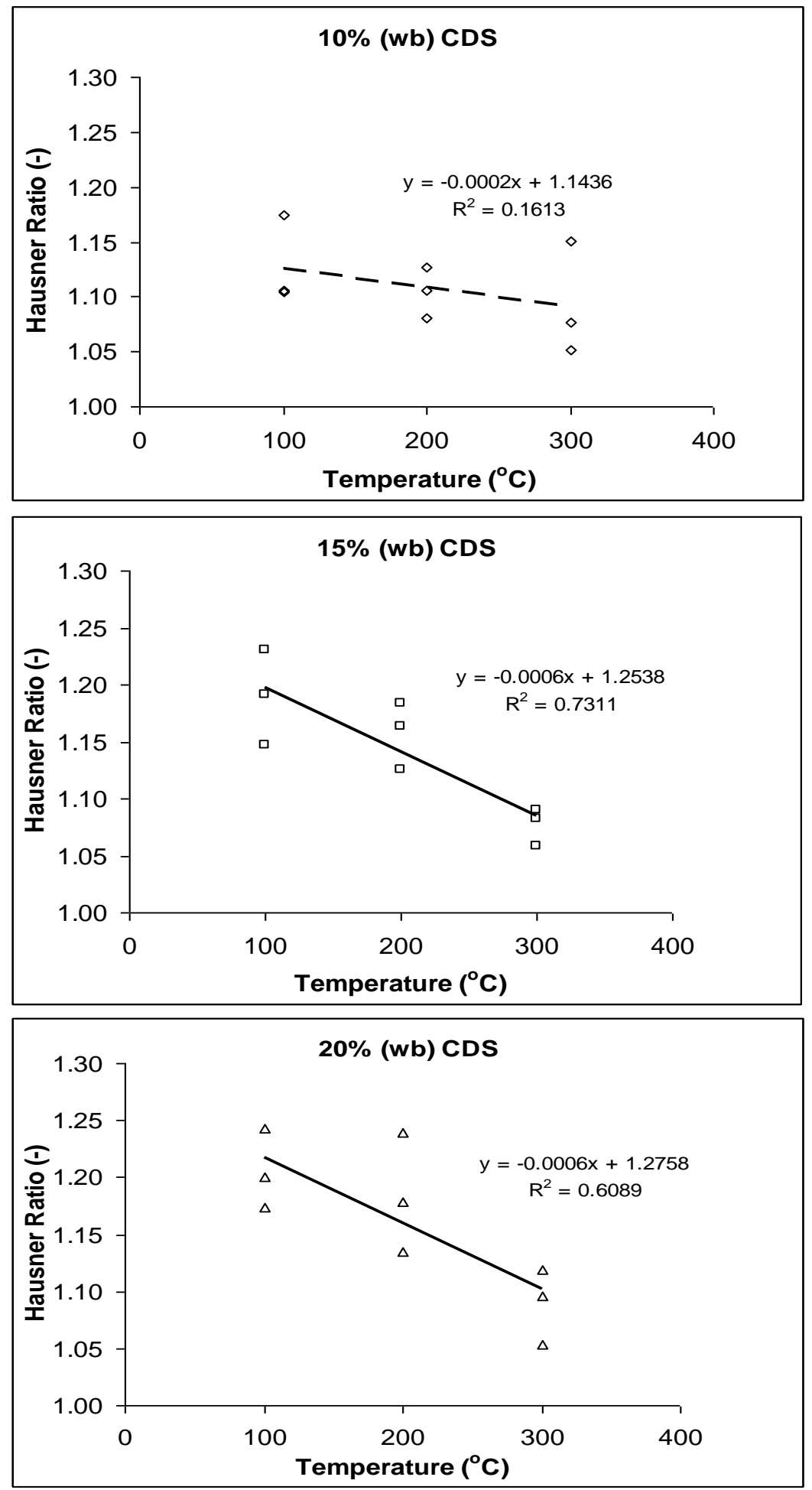

Figure 1: Relationships between Hausner Ratio and drying temperature according to CDS level. 

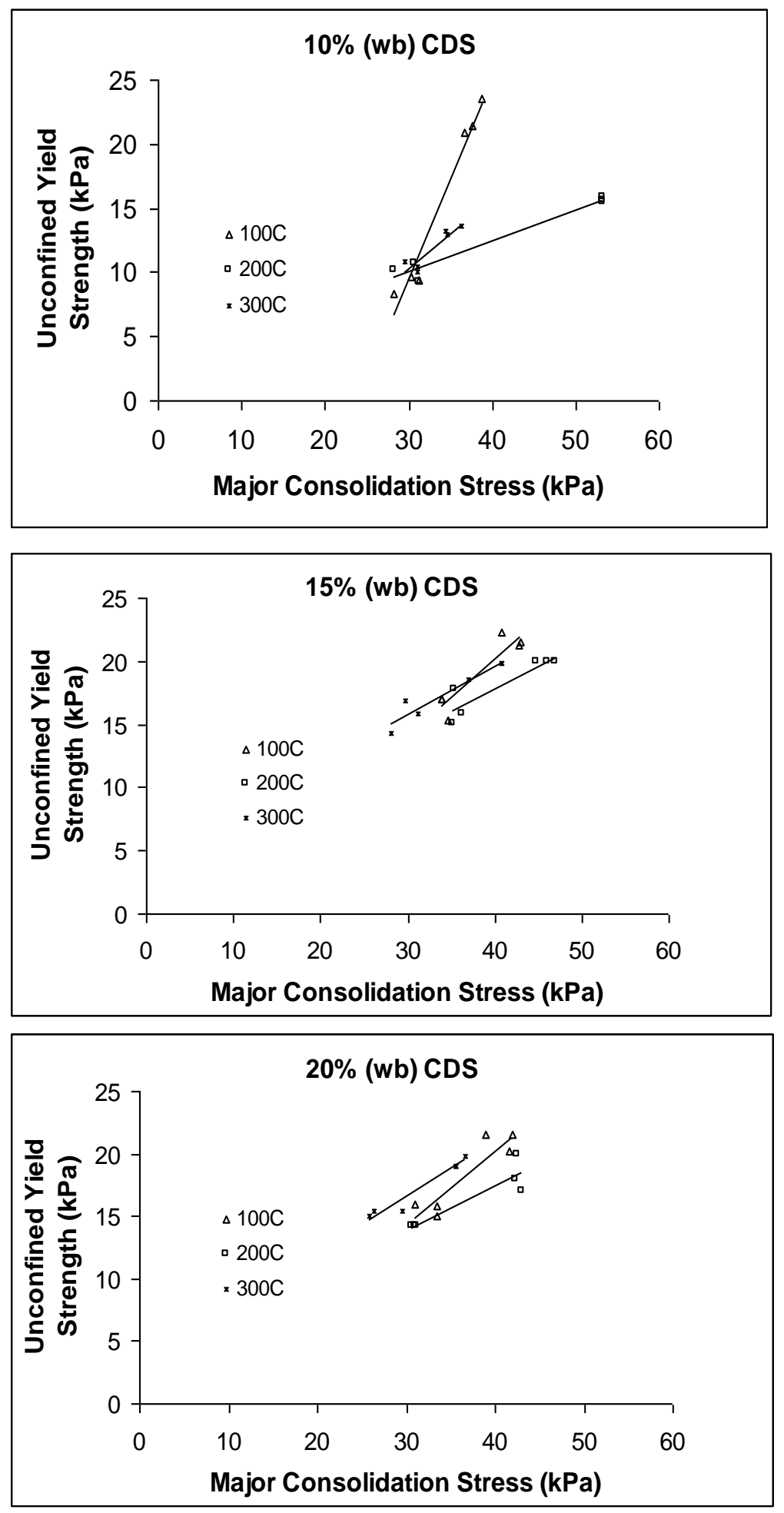

Figure 2: Relationships between unconfined yield strength $\left(\sigma_{c}\right)$, major consolidation stress $\left(\sigma_{1}\right)$, (which are known as Jenike Flow Function curves), and drying temperature according to CDS level. 

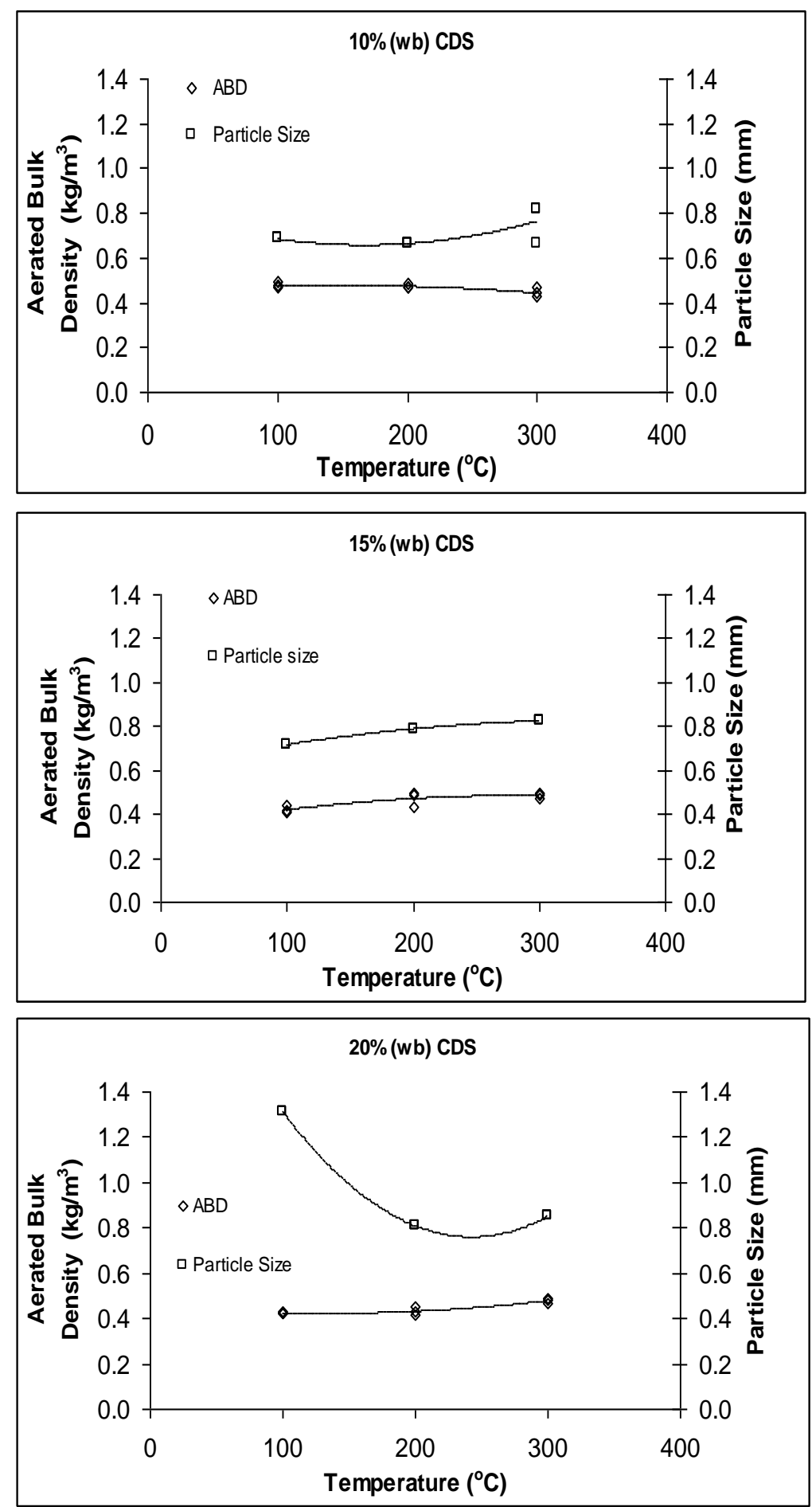

Figure 3: Relationships between aerated bulk density (ABD), particle size, and drying temperature according to CDS level. Particle size is defined as geometric mean diameter $\left(d_{g w}\right)$. 

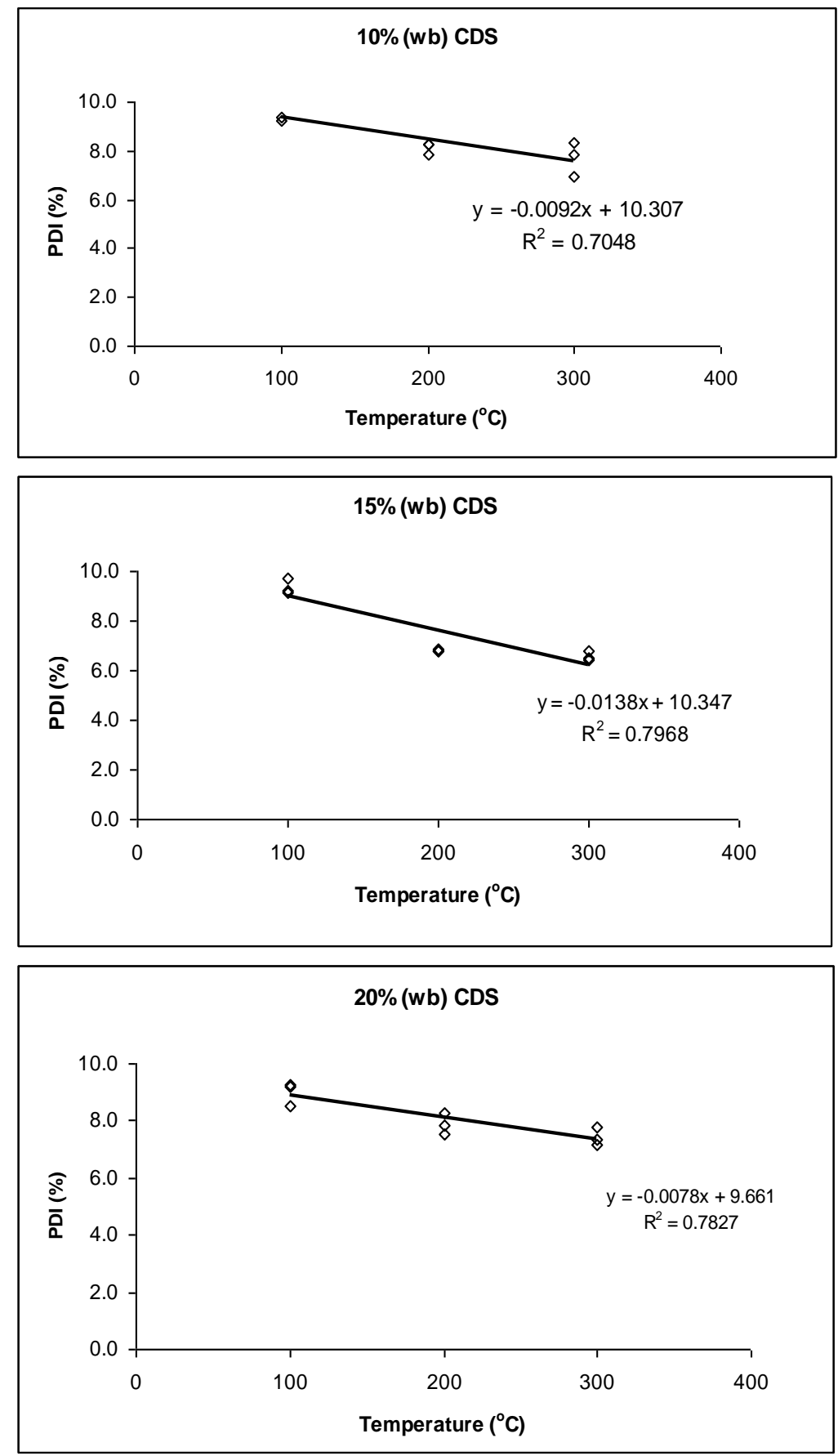

Figure 4: Relationships between protein dispersibility index (PDI) and drying temperature according to CDS level. 

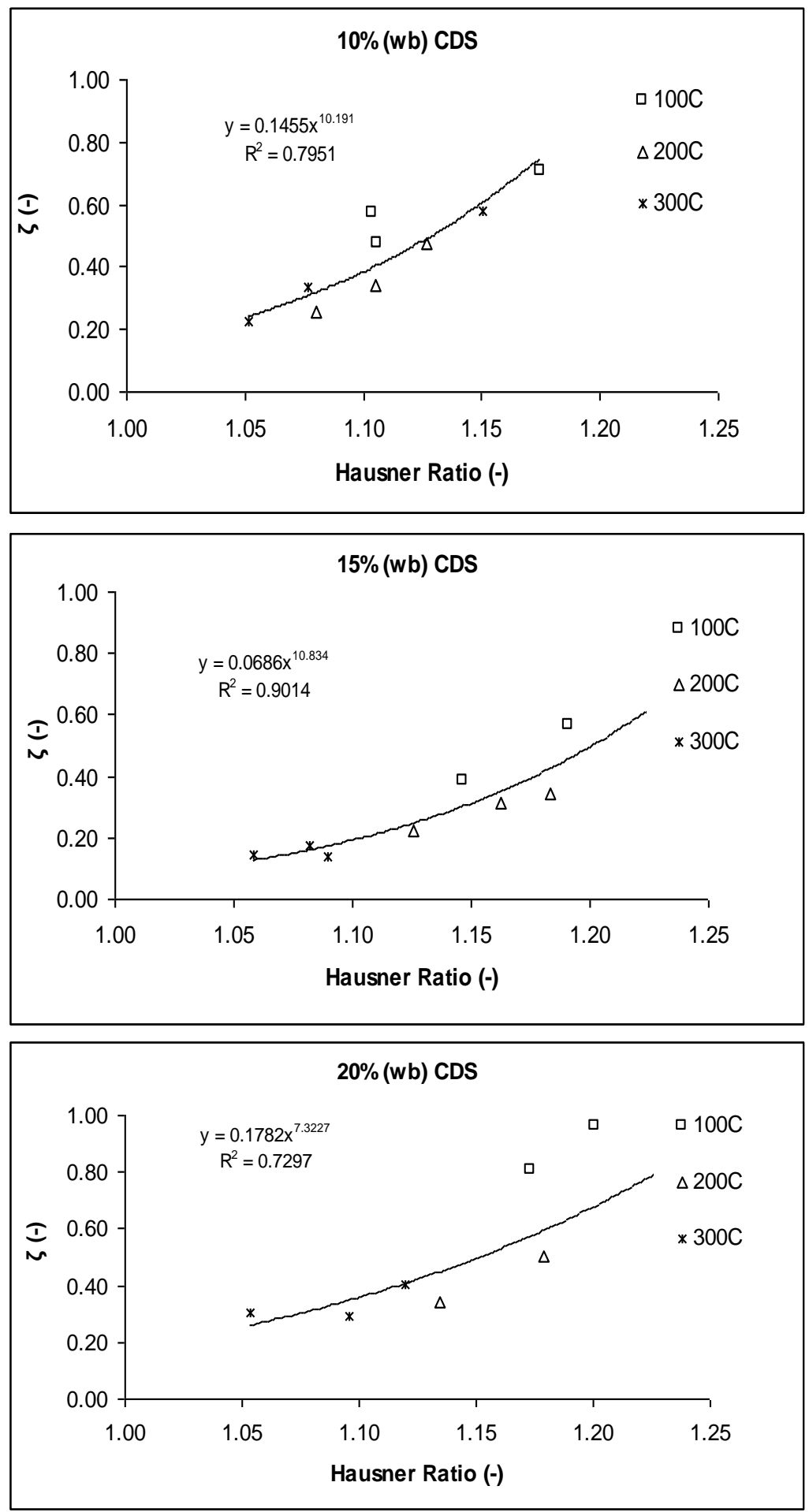

Figure 5: Validation of empirical flowability model (from Ganesan et al., 2007b) by fitting power law regression equations according to $\mathrm{CDS}$ level; $\zeta$ is defined as $\left(C_{c} /\right.$ Dispersibility $) *(\delta / \Phi)$. 

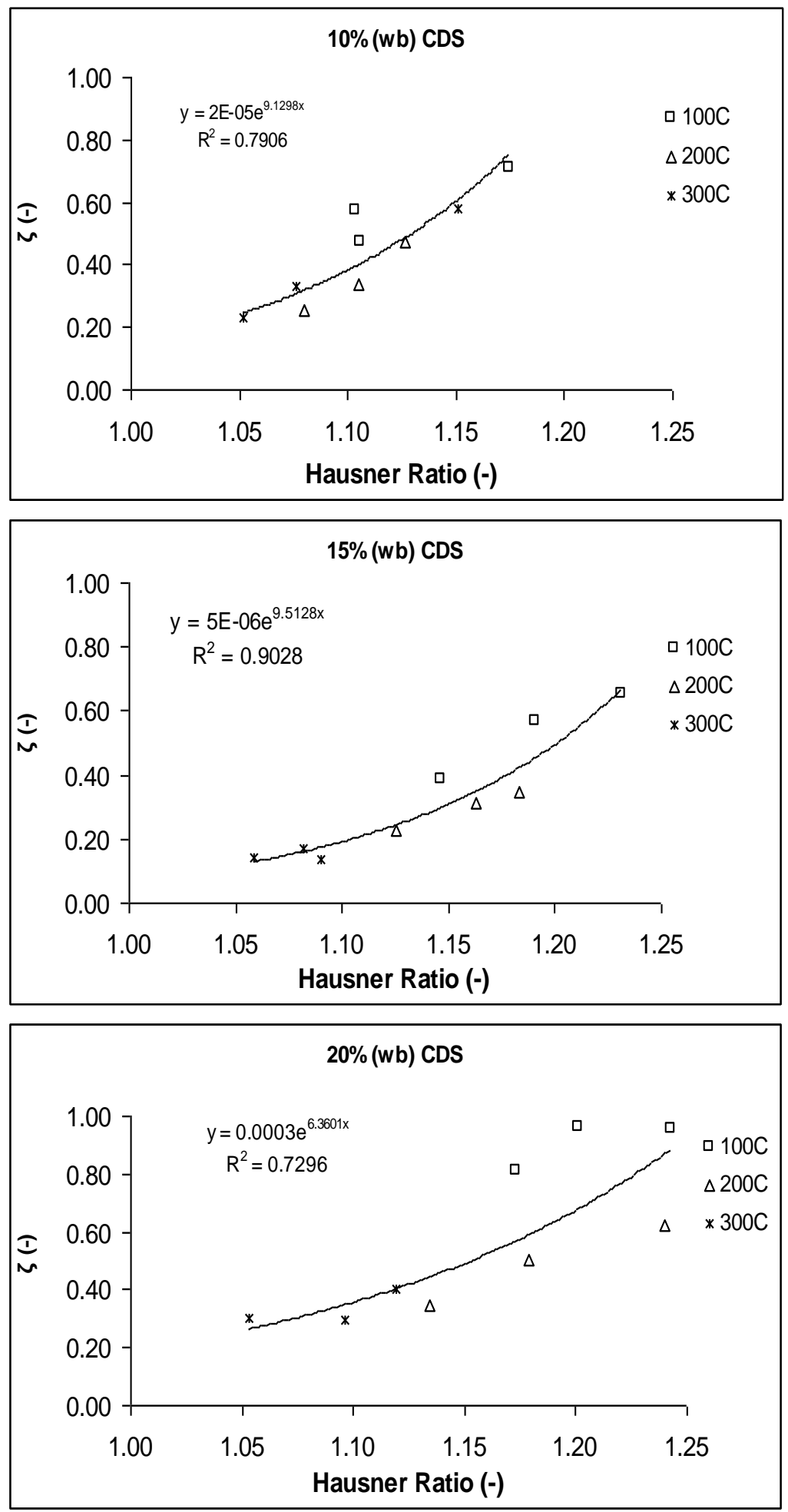

Figure 6: Validation of empirical flowability model (from Ganesan et al., 2007b) by fitting exponential regression equation, according to CDS level; $\zeta$ is defined as $\left(\mathrm{C}_{\mathrm{c}} / \text { Dispersibility }\right)^{*}(\boldsymbol{\delta} / \Phi)$. 


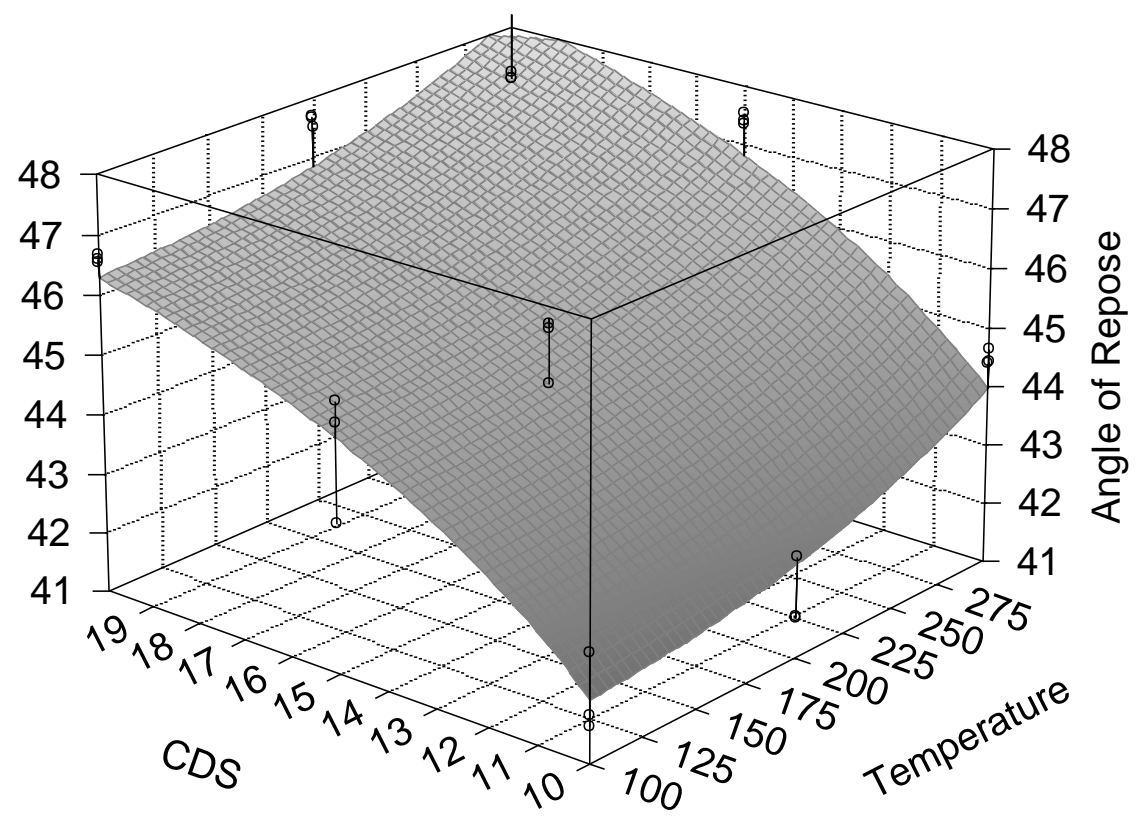

Figure 7: Surface plot showing the relationship between drying temperature $\left({ }^{\circ} \mathrm{C}\right), \mathrm{CDS}$ level $(\% \mathrm{wb})$, and angle of repose $\left({ }^{\circ}\right)$. 


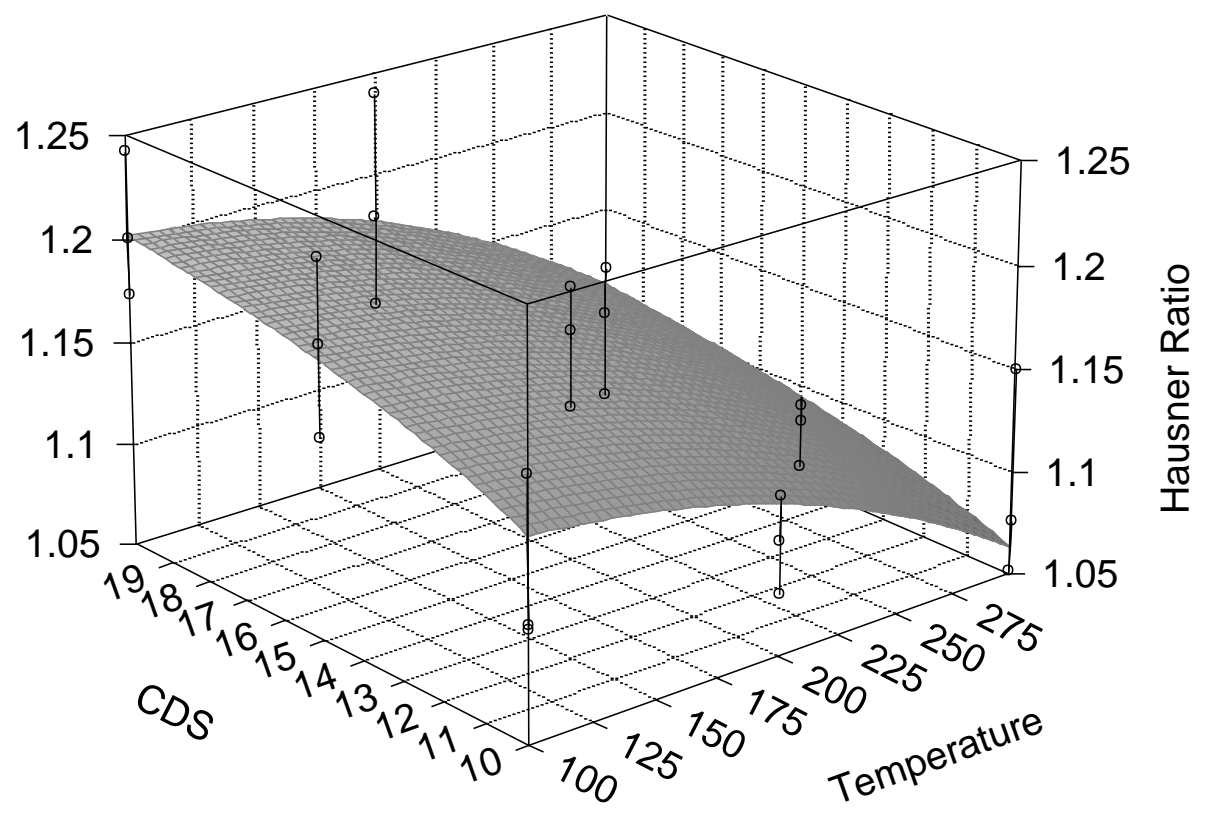

Figure 8: Surface plot showing the relationship between drying temperature $\left({ }^{\circ} \mathrm{C}\right), \mathrm{CDS}$ level (\% wb), and Hausner Ratio (-). 


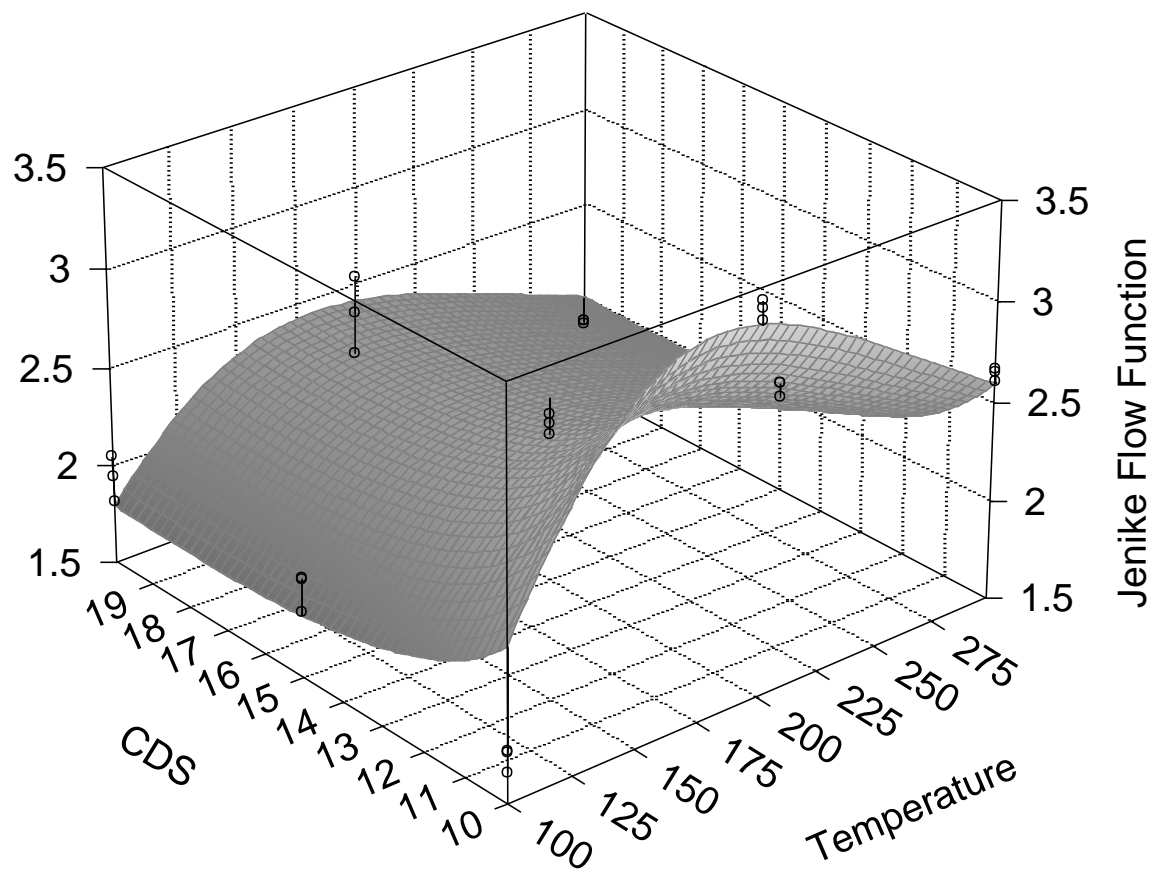

Figure 9: Surface plot showing the relationship between drying temperature $\left({ }^{\circ} \mathrm{C}\right), \mathrm{CDS}$ level (\% wb), and Jenike Flow Function Index (-) [note that Jenike Flow Function Index is also known as Jenike Flow Index (-)]. 


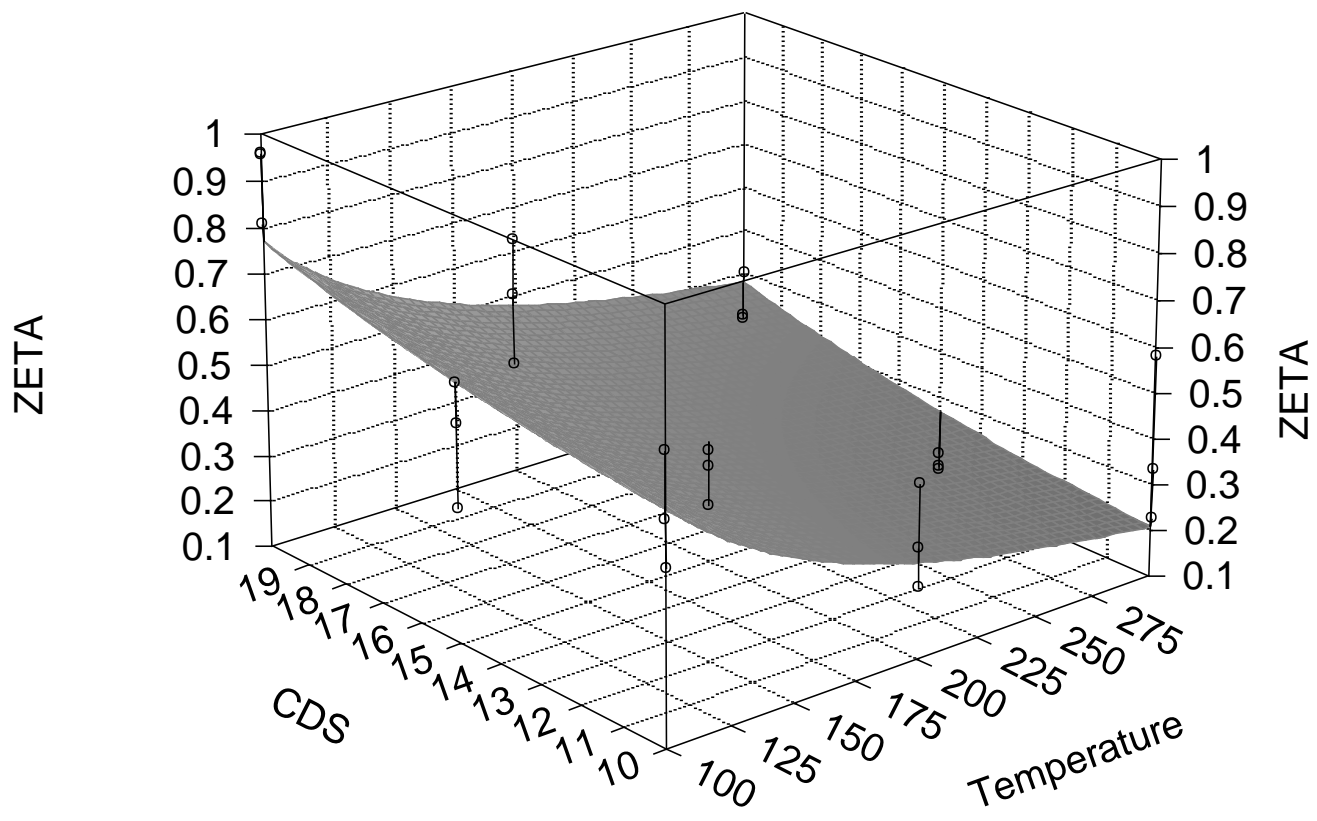

Figure 10: Surface plot showing the relationship between drying temperature $\left({ }^{\circ} \mathrm{C}\right)$, CDS level (\% wb), and zeta $(\zeta,-)$. Zeta is the empirical flowability indicator. 


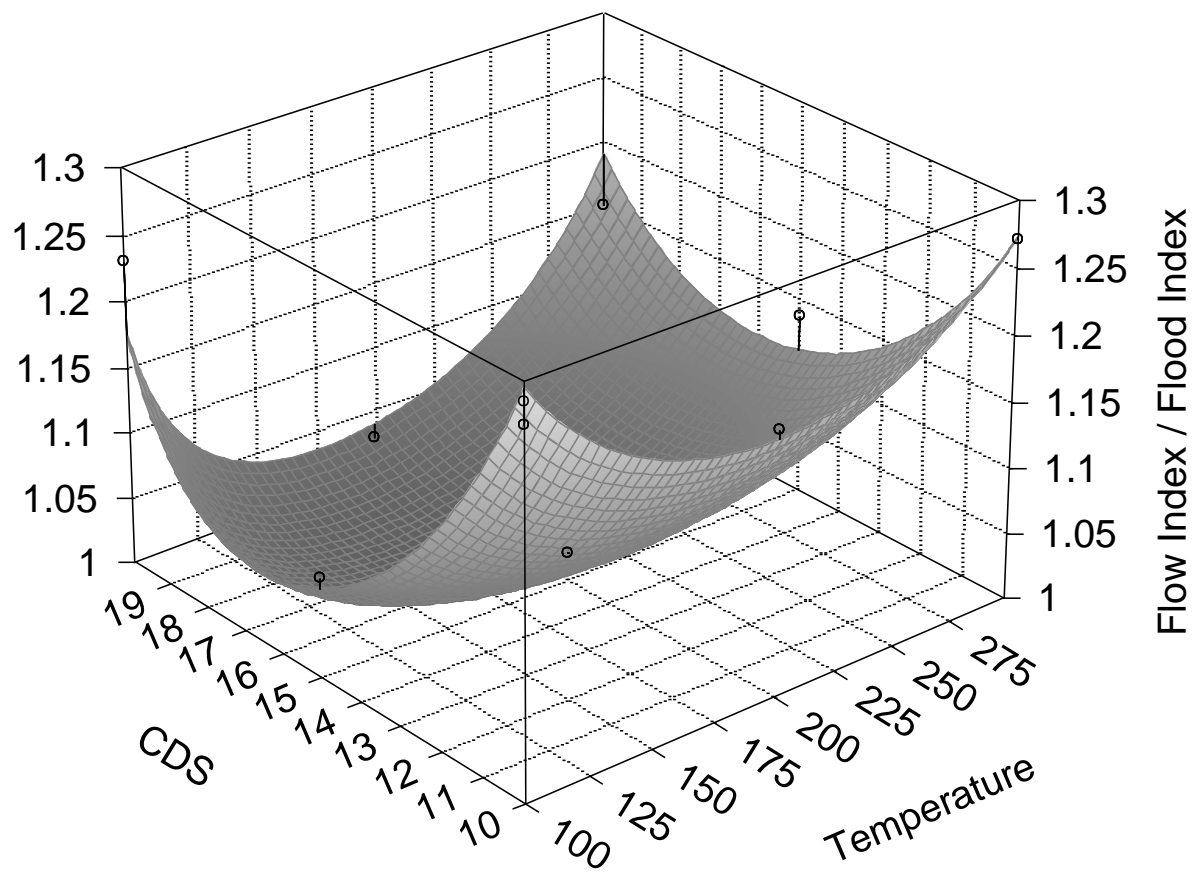

Figure 11: Surface plot showing the relationship between drying temperature $\left({ }^{\circ} \mathrm{C}\right)$, CDS level (\% wb), and the ratio of Total Flow Index/Total Flood Index. 


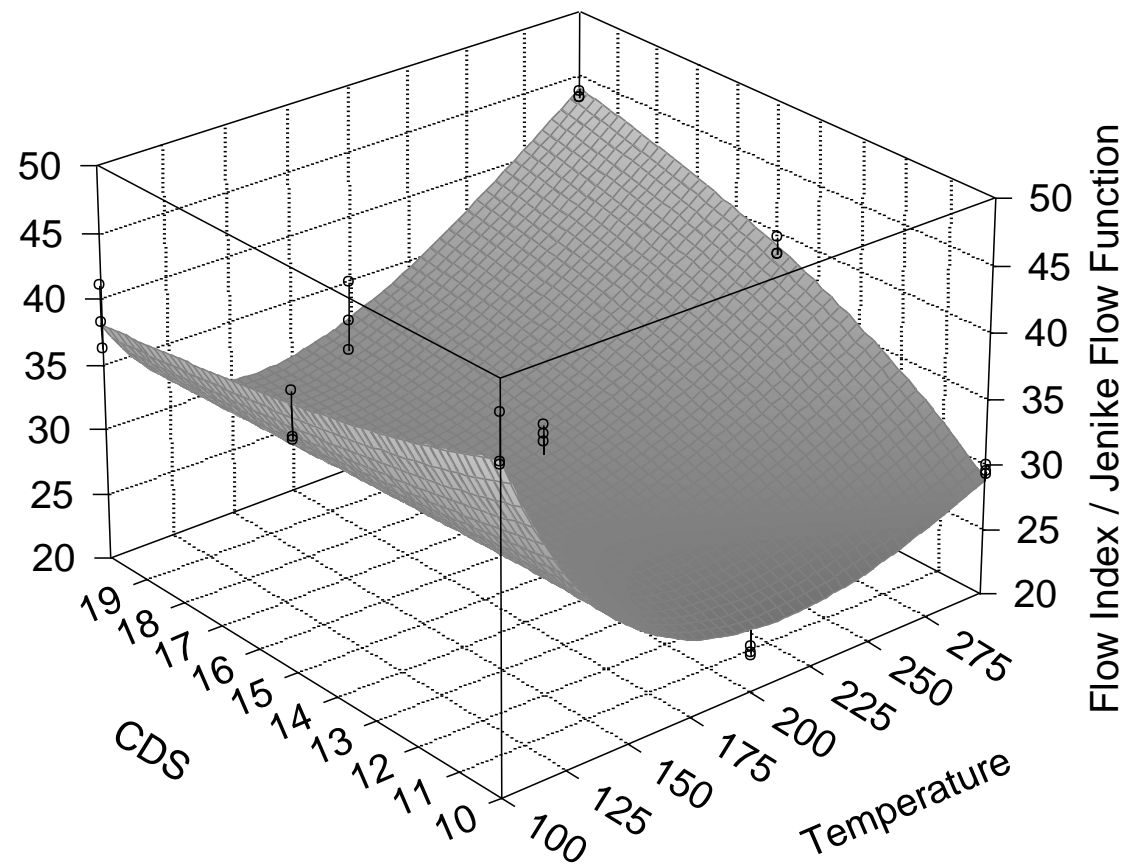

Figure 12: Surface plot showing the relationship between drying temperature $\left({ }^{\circ} \mathrm{C}\right)$, CDS level (\% wb), and the ratio of Total Flow Index/Jenike Flow Function Index [note that Jenike Flow Function Index is also known as Jenike Flow Index (-)]. 

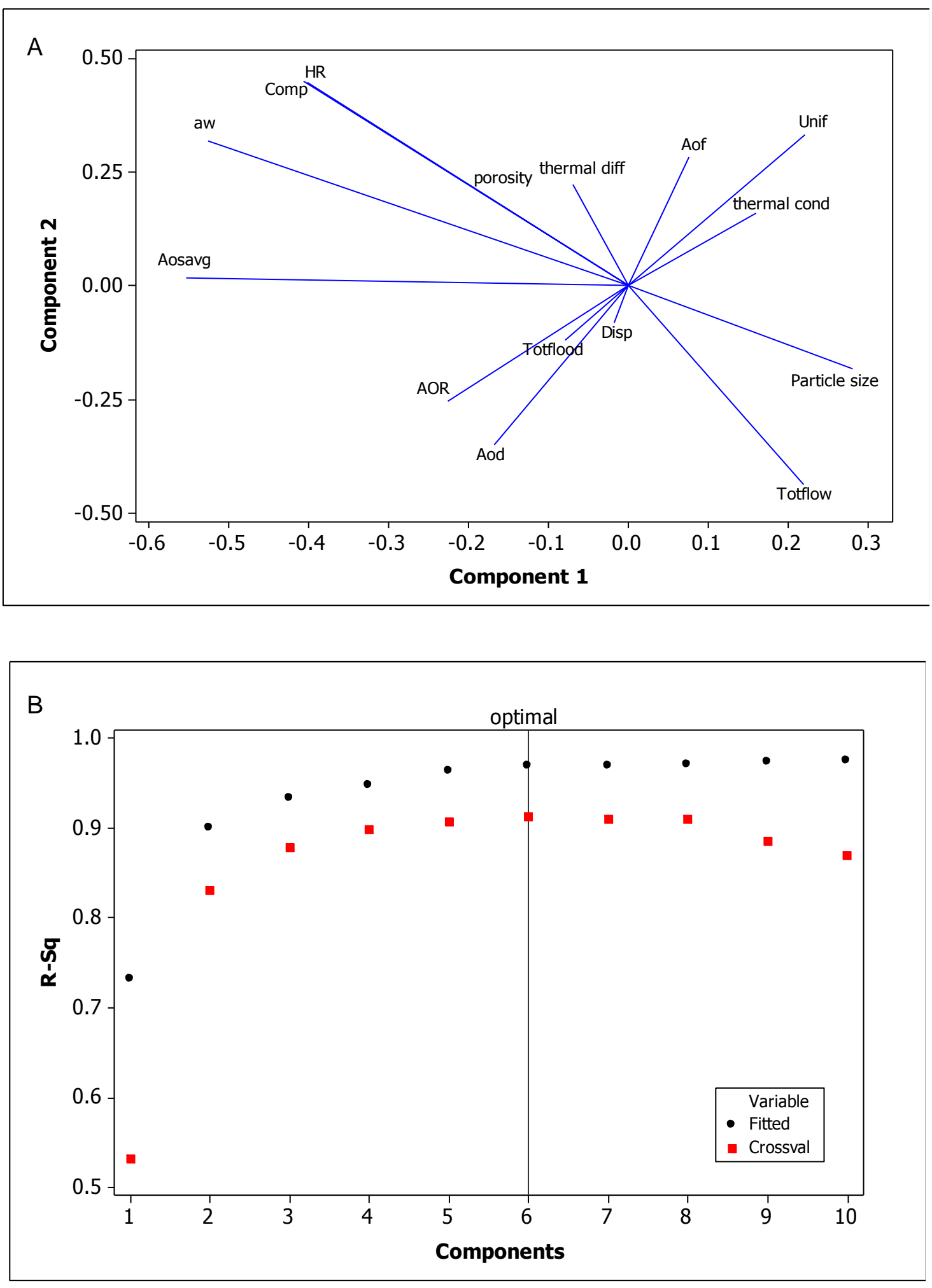

Figure 13. Partial Least Square (PLS) regression results for Jenike Flow Function Index as a multivariate function of all flow and physical properties (excluding Jenike properties); (A) loading plot; (B) model selection plot for the PLS analysis. ["R-sq" is the coefficient of determination $\left(\mathbf{R}^{2}\right)$; "Fitted" indicates the fitted PLS regression line; "Cross val" is cross validation, which is a 
multivariate procedure used to predict and validate the PLS regression curve by using alternative data points from the entire data set and testing the line fit]. 